\title{
Zooming in on Heinrich layers
}

\author{
Francis E. Grousset, 'Elsa Cortijo, ${ }^{2}$ Sylvain Huon, ${ }^{3}$ Laurence Hervé, \\ Thomas Richter, 1,4 Didier Burdloff, ${ }^{1,3}$ Josette Duprat, ' and Olivier Weber'
}

\begin{abstract}
Theories explaining the origin of the abrupt, massive discharges of ice-rafteddetritus (IRD) into the glacial North Atlantic (the Heinrich layers (HLs)) generally point to the Laurentide ice sheet as the sole source of these events, until it was found that the IRDs also originated from Icelandic and European ice sheets [Bond and Lotti, 1995; Snoeckx et al., 1999; Grousset et al., 2000]. This apparent contradiction must be reconciled as it raises fundamental questions about the mechanism(s) of HL origin. We have analyzed two $\sim 12 \mathrm{~cm}$ thick HLs in an ultrahigh-resolution mode (1-2 century intervals) in a mid-Atlantic ridge piston core. The $\delta^{18} \mathrm{O}$ record $(N$. pachyderma left coiling) reveals strong excursions induced by the melting of the icebergs; these excursions are associated with a strong decrease in the amount of planktic foraminifersand with a $3^{\circ} \mathrm{C}$ cooling of the surface waters. Counts of coarse detrital grains reveal that IRD are deposited according to a typical sequence (1) volcanic glass, (2) quartz and feldspars, (3) detrital carbonate, that implies a chronology in the melting of the differentpan-Atlantic ice sheets. Sr and $\mathrm{Nd}$ isotopic composition confirm that in both Heinrich layers $\mathrm{H} 1$ and H2, "precursor" IRD came from first Europe/Iceland, followed then by Laurentide-derived IRD. An internal cyclicity can be identified: during $\mathrm{H} 1$ and $\mathrm{H} 2$, about four to six major, abrupt discharges occurred roughly on a century timescale. The $\delta^{13} \mathrm{C}$ and $\delta^{15} \mathrm{~N}$ records reveal that dominant inputs of continent-derived organic matter are associated with IRD within the HLs, hiding the plankton productivity signal.
\end{abstract}

\section{Introduction}

It is well known that most of the typical Heinrich events are characterized by massive abrupt discharges of icebergs released by the periodic collapse of the Laurentide ice sheet. The Laurentide perhaps oscillates according to its internal dynamics with $\mathrm{a} \approx 7.200$ year cycle [McAyeal, 1993; Alley and McAyeal, 1994]. It has been shown, however, that other ice sheets, such as the Icelandic, also contributed to these events [Bond and Lotti, 1995]. Moreover, more rapid cycles $(\approx 1-2$ kyr) seem to have occurred between the typical Heinrich layers (HLs) [Bond and Lotti, 1995]. Elliot et al. [1998] hypothetized that the European ice sheets could have more likely oscillated with $\mathrm{a} \approx 1-2 \mathrm{ky}$ cycle, while Laurentide surges would have occurred every $\approx 7.2 \mathrm{kyr}$. The origin of these cycles is not fully understood yet.

More recent work has provided a few lines of evidence that the European ice sheets also contributed to the story [Snoeckx et al., 1999] and that IRDs were first released by these European ice sheets, followed by the Laurentide [Grousset et al., 2000; Scourse et al., 2000]. This observation may open a door to a better understanding of the mechanisms that drove

\footnotetext{
'Département de Géologıe et Océanographie, UMR 5805 EPOC, Université Bordeaux I, Talence, France

?Laboratoire des Sciences du Climat et de l'Environnement, CNRS. CEA, Gif sur Yvette, France.

${ }^{3}$ BıoGéochımie lsotopique, Unıversité Paris 6, Paris, France.

'Now at Nederlands Instituut voor Onderzoek der Zee, AB Den Burg, Texel, The Netherlands.
}

Copyright 2001 by the American Geophysical Union.

Paper number 2000PA000559.

0883-8305/01/2000PA000559\$12.00 these events. Whether these precursor European events triggered the major Laurentide surges or the behavior of the different pan-Atlantic ice sheets followed a totally independant cyclicity is still debated. One could probably better understand the origin of the Heinrich events by examining in detail the successive steps of their life.

In this work, we propose to better elucidate the internal structure of the three most recent HLs by analyzing a series of various parameters in an extremely high resolution mode (every $5 \mathrm{~mm}$, i.e., every 1-2 centuries) in a core located in the ice-rafted detritus (IRD) belt [Ruddiman, 1977]: SU90-09. We propose to study several paleoclimatic proxies (foraminifer abundance, $\delta^{18} \mathrm{O}$, sea surface temperature (SST)), the geochemical and petrological composition of the IRD ( $\mathrm{Sr}$ and Nd isotopes and coarse-grained petrology), the isotopic composition of the organic matter $\left(\delta^{13} \mathrm{C}\right.$ and $\left.\delta^{15} \mathrm{~N}\right)$, and the elemental composition of the bulk sediments. This comprehensive approach should allow us to identify the internal structure of the HLs, which could lead to better understanding their origin.

\section{Material and Methods}

\subsection{Material}

Core SU90-09 was raised from the western side of the MidAtlantic Ridge $\left(\approx 43^{\circ} 05^{\prime} \mathrm{N}, \approx 31^{\circ} 05^{\prime} \mathrm{W}, 3.375 \mathrm{~m}\right.$ water depth) (Figure 1). This piston core is located on the southern border of the IRD belt [Ruddiman, 1977], $70 \mathrm{~km}$ west of the extensively studied core SU90-08 [Grousset et al., 1993; Revel et al., 1996; Cortijo et al., 1997; Vidal et al.. 1997; Elliot et al., 1998]. Our present study is focused on the upper $120 \mathrm{~cm}$ of SU90-09, which contain the three most recent HLs (H1, H2, and $\mathrm{H} 3$ ). 


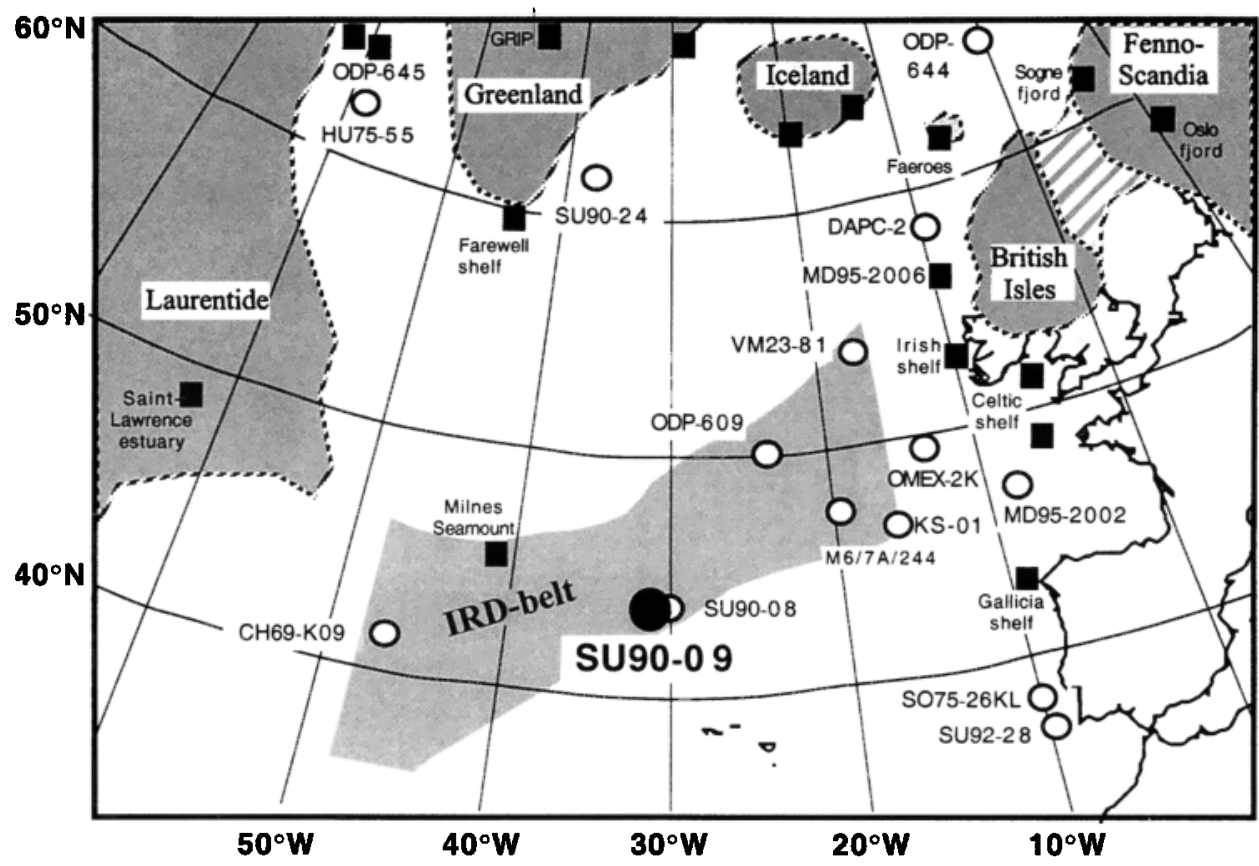

Figure 1 Location of core SU90-09 (solid circle) and of other cores cited in the discussion (open circles). Location of ice sheets is shown by stippled area on land and corresponds to the approximate maximum ice sheet extension at Last Glacial Maximum (LGM). Stippled area in North Atlantıc shows position of the ice-rafted detritus (IRD) belt [Ruddıman, 1977] . Possible Source Areas (PSAs) are fingerprinted using the coarse $(>63 \mu \mathrm{m})$ fraction of carbonate-free sedıments recovered from fjord, estuarine, or continental shelf areas (solid squares).

\subsection{Methods}

Whole-core, low-field magnetic susceptibility was measured with a pass-through Bartington magnetometer. This instrument integrates the sediment section within a small coil (4 $\mathrm{cm}$ diameter) to record the changes in magnetic susceptibility along a continuous subsampling of core SU9009, made using a transparent, PVC, U-shaped channel. Resolution after deconvolution of the signal is of the order of $\approx 2 \mathrm{~cm}$. The grey level reflectance of core SU90-09 has been analyzed following Bond et al. [1992]. Sedimentary sequences, lithologic facies, and the geometry of physical and biological structures were observed using a digital SCOPIX $\mathrm{X}$-ray device, coupling a high-energy brightness amplifier and a digital camera [Migeon et al., 1999]. Smear slides were fabricated after induration with a polyesther resin in order to identify bioturbation, if any. Sediment slices were then sampled at $1 \mathrm{~cm}$ intervals and at $0.5 \mathrm{~cm}$ intervals through the Heinrich layers, using an electro-osmotic cutter.

Stratigraphy was provided by $\delta^{18} \mathrm{O}$ isotopic analysis performed at $1 \mathrm{~cm}$ intervals on the coarse fraction $(150-250 \mu \mathrm{m})$ of planktonic foraminifera Neogloboquadrina pachyderma (left coiling (lc), and at $0.5 \mathrm{~cm}$ intervals through the Heinrich layers, from 30 to $118 \mathrm{~cm}$. Nine ${ }^{14} \mathrm{C}$ accelerator mass spectrometry (AMS) ages (B.P.) were obtained on foraminifera $N$. pachyderma (lc) $(>150 \mu \mathrm{m})$ and corrected into conventional radiocarbon ages by taking into account ${ }^{13} \mathrm{C} /{ }^{12} \mathrm{C}$ ratios. These ${ }^{14} \mathrm{C}$ ages were finally corrected for a 400 year reservoir age [Bard, 1988]. Error bars are $\leq 100$ years. The ${ }^{14} \mathrm{C}$ ages have also been transformed into calendar ages, using regression equations derived from Bard et al. [1988, 1998] and Stuiver et al. [1998] (see Figures 2 and 3).
Carbon and nitrogen stable isotopes $\left(\delta^{13} \mathrm{C}\right.$ and $\left.\delta^{15} \mathrm{~N}\right)$ were measured by elemental analyzer coupled with an isotope ratio mass spectrometer (EA-IRMS) on bulk organic matter of $<50$ $\mu \mathrm{m}$ size fractions. Calcite and dolomite removal was previously performed using a careful $\mathrm{HCl}$ dissolution procedure extensively described by $\mathrm{S}$. Huon et al. (Sources of fine organic matter in the North Atlantic Heinrich layers: $\delta^{13} \mathrm{C}$ and $\delta^{15} \mathrm{~N}$ isotope tracers, submitted to Geochimica Cosmochimica Acta, 2001). The $\delta^{13} \mathrm{C}$ and $\delta^{15} \mathrm{~N}$ are reported in per mil and refer to Pee dee Belemnite (PDB) and air as standards [Coplen et al., 1983]. Analytical precision is better than $\pm 0.1 \%$ and $\pm 0.2 \%$ for $\delta^{13} \mathrm{C}$ and $\delta^{15} \mathrm{~N}$, respectively. Bulk organic carbon (TOC) and total nitrogen contents (TN) are reported in $\mathrm{mg} \cdot \mathrm{g}^{-1}$ of sediment (equivalent to per mil) and were determined with $a \pm$ $0.1 \%$ constant uncertainity. Owing to the low nitrogen content of the samples (0.1-0.7\%o), only a fair precision was obtained with calculated TOC/TN ratios. Therefore they were not used in this study.

Samples were sieved in order to analyze the coarse $>150$ $\mu \mathrm{m})$ fraction. This grain-size fraction was selected according to Bond et al. [1992]. Particles were counted under the binocular microscope, distinguishing quartz, feldspars, micas, rock fragments, detrital carbonate, and volcanic glass. Counts of foraminifera species allowed us to reconstruct sea surface temperature (SST) for both winter and summer seasons, using the modern analog technique [Prell, 1985]. Mean error bars on SST evaluations are about $\pm 1^{\circ} \mathrm{C}$.

Carbonate was dissolved using $0.6 \mathrm{~N} \mathrm{HCl}$, and the carbonate-free coarse $(>63 \mu \mathrm{m})$ fraction was crushed in a grinder. This grain-size fraction $(>63 \mu \mathrm{m})$ was chosen in order to be consistent with previous data obtained on the same 
fraction [Snoeckx et al., 1999]. About $10 \mathrm{mg}$ aliquots were dissolved with a mixture of teflon-distilled $\left[\mathrm{HF}+\mathrm{HClO}_{4}+\right.$ $\mathrm{HNO}_{3}$ ]. $\mathrm{Sr}$ and $\mathrm{Nd}$ were chemically separated through ionic chromatographic columns in a "class-1000" clean laboratory. We followed chemical and mass spectrometer techniques previously described [Grousset et al., 1998]. Thermo ionisation mass spectrometry analysis of $\mathrm{Sr}$ and $\mathrm{Nd}$ was done on a Finnigan MAT 261 mass spectrometer. The measured ${ }^{87} \mathrm{Sr} /{ }^{86} \mathrm{Sr}$ and ${ }^{143} \mathrm{Nd} /{ }^{144} \mathrm{Nd}$ ratios were corrected for mass fractionation by normalizing to ${ }^{86} \mathrm{Sr} /{ }^{88} \mathrm{Sr}=0.1194$ and ${ }^{146} \mathrm{Nd} /{ }^{144} \mathrm{Nd}=0.7219$, respectively. For convenience, ${ }^{143} \mathrm{Nd} /{ }^{144} \mathrm{Nd}$ ratios are normalized and reported as follows: $\varepsilon_{\mathrm{Nd}}(0)=\left(\left({ }^{143} \mathrm{Nd} /{ }^{144} \mathrm{Nd} / 0.512636\right)-1\right) \times 10^{4}$, in which 0.512636 is the chondritic uniform reservoir value [Jacobsen and Wasserburg, 1980]. Sr standard NIST 987 was measured seven times with an average ${ }^{87} \mathrm{Sr} /{ }^{86} \mathrm{Sr}=0.710242( \pm 0.000017)$ versus the certified value of 0.710250 , and the French Nd standard "Rennes" was analyzed five times with an average ${ }^{143} \mathrm{Nd} /{ }^{144} \mathrm{Nd}=0.511974( \pm 0.000014)$ versus the recommended value of 0.511962 . Blanks were measured $\left(\mathrm{Sr}<10^{-9} \mathrm{~g}\right.$ and $\mathrm{Nd}<2.10^{-10} \mathrm{~g}$ ) and are considered to be negligible in all cases.

\section{Results}

A clear relationship exists between grey scale and magnetic susceptibility records in both cores, at least in the depth distribution of the peaks (Figures 2-3). Both records in core SU90-09 are similar enough to the SU90-08 records of Grousset et al. [1993] to infer the position of most of the Heinrich layers (H1-H6) in SU90-09, with only $\mathrm{H3}$ and $\mathrm{H6}$ not well represented. Using the 19 AMS ${ }^{14} \mathrm{C}$ dates obtained on both cores, the timescale of the core can be then derived. Ages of the $\mathrm{H} 1$ and $\mathrm{H} 2$ boundaries (Figure 3) are consistent with ages obtained in other cores from North Atlantic [Elliot et al., 1999; Grousset et al., 2000; Scourse et al., 2000]. The average accumulation rate is $\sim 4.3 \mathrm{~cm}$. $\mathrm{kyr}^{-1}$ but increases up to $8 \mathrm{~cm}$. $\mathrm{kyr}^{-1}$ during $\mathrm{Hl}$. AMS ${ }^{14} \mathrm{C}$ dates obtained for this core yield the duration of these events: $\approx 1.4 \mathrm{kyr}$ for $\mathrm{HI}$ and $\approx 2.1$ kyr for $\mathrm{H} 2$. These durations imply accumulation rates of 15.3 and $11.0 \mathrm{~g} \mathrm{~cm}^{-2} . \mathrm{kyr}^{-1}$ for $\mathrm{H1}$ and $\mathrm{H} 2$ respectively. Such fluxes are consistent with those calculated using ${ }^{230} \mathrm{Th}$ activity in the neighbor core CHN82-31-11PC recovered $80 \mathrm{~km}$ away from SU90-09: 19.0 and $11.0 \mathrm{~g} . \mathrm{cm}^{-2} . \mathrm{kyr}^{-1}$ for $\mathrm{Hl}$ and $\mathrm{H} 2$, respectively [François and Bacon, 1994].

$\mathrm{X}$-radiographs of thin sediment slices do not reveal any structure, such as hiatus, erosion surface, or any physical perturbation. HLs are clearly identified as dark zones owing to increased IRD and water content decrease; they are characterized by abundant, coarse (millimeter-to-centimeter) particle deposits, alternating with thin (3-5 mm) layers of "regular" glacial sediments, comparable to the ambient sediments between the HLs. Bioturbation (worm burrows) is only visible in the ambient glacial deposits located between the events, as already observed in core KS-01 [Auffret et al., 1996] (see Figure 1 for location). This evidence of unbioturbated, laminated deposits alternating with badly sorted IRD is confirmed by microscopic examination of the HL lithofacies, realized on smear-slides under cross -nicols.

The high-resolution study has been limited to the three last HLs. In the following figures $3,4,5$, and 7 , however, depths will be expressed in centimeters instead of kiloyears, in order to avoid a strong compression of the records within the HLs due to the high accumulation rates characterizing these events.

\subsection{Planktic Foraminifers}

HLs are marked by a darkening of the sediment color (Figure 3 ), reflecting a decrease in the proportion of carbonate plankton. In the HLs, the number of foraminifers is 1 order of magnitude smaller than between these events (Table 1). This decrease is associated with a change in the species proportions. During the HLs, $N$. pachyderma (lc) becomes dominant (up to $80 \%$ ), and their $\delta^{18} \mathrm{O}$ composition becomes lighter, displaying brief excursions of $\sim 0.6-1.0 \%$, that paralle] similar anomalies already reported for the neighboring core SU90-08 [Cortijo et al., 1997]. These excursions are maximal during the upper part of the HLs. They are associated with a sudden decrease of $3^{\circ} \mathrm{C}$ of the mean SST, shifting them from $11^{\circ} \mathrm{C}$ down to $8^{\circ} \mathrm{C}$ during the summers (Figure 3) and from $6^{\circ} \mathrm{C}$ down to $3^{\circ} \mathrm{C}$ during the winters. When combining both SST and $\delta^{18} \mathrm{O}$, it can be estimated that paleosalinity decreased by $\approx 2 \%$ during both $\mathrm{H} 1$ and $\mathrm{H} 2$.

(SSS)

\subsection{Lithic Grains}

Lithic grains were counted on the coarse $(>150 \mu \mathrm{m})$ fraction under a binocular microscope. Their abundance increases by a factor of 10 during the HLs. A few minerals were distinguished and counted: quartz, feldspars, micas, rock fragments, detrital carbonate, and volcanic glass (Table 2). The most representative are presented in Figure 4 (detrital carbonate, volcanic glass and quartz). All these minerals display strong increases during the HLs, although their maximumoccurrence is not always simultaneous. Volcanic grains increase first, at the beginning of the HLs, followed by quartz, and finally by detrital carbonate. This pattern is visible in both $\mathrm{H} 1$ and $\mathrm{H} 2$. On the contrary, $\mathrm{H} 3$ does not display any structure. Within the HLs the mineral abundance is cyclic, displaying centennial-like subevents.

Secondary lithic peaks observed between the HLs in some other cores were attributed to Dansgaard-Oeschger cycles [Bond and Lotti, 1995; Elliot et al., 1998; van Kreveld et al., 2000]. Such secondary events are hardly visible in core SU9009 , probably because this core is located too far south.

\subsection{Isotopic (Sr-Nd) Composition of IRD}

The down core variation of the $\mathrm{Sr}$ and $\mathrm{Nd}$ isotopic composition of the carbonate-free coarse $(>63 \mu \mathrm{m})$ fraction is displayed in Figure 5 and Table 3. Within the Heinrich layer, IRD are characterized by radiogenic $\mathrm{Sr}\left(0.72<87 \mathrm{Sr} /{ }^{86} \mathrm{Sr}<0.73\right)$ and unradiogenic $\mathrm{Nd}\left(-45<\varepsilon_{\mathrm{Nd}}(0)<-20\right)$. Within these intervals the isotopic values are characterized by a highfrequency variability. These layers are preceeded by a narrow (3-4 cm thick) event displaying much less radiogenic $\mathrm{Sr}$ $\left(0.715<^{87} \mathrm{Sr} /{ }^{86} \mathrm{Sr}<0.718\right)$ and much more radiogenic $\mathrm{Nd}$ $\left(-16<\varepsilon_{N d}(0)<-6\right)$. Very similar patterns are observed for both isotopes in both $\mathrm{H} 1$ and $\mathrm{H} 2$.

In Figure 6a we have plotted ${ }^{87} \mathrm{Sr} /{ }^{86} \mathrm{Sr}$ ratios against $\varepsilon_{\mathrm{Nd}}(0)$ for all the possible source areas (PSA) from the 


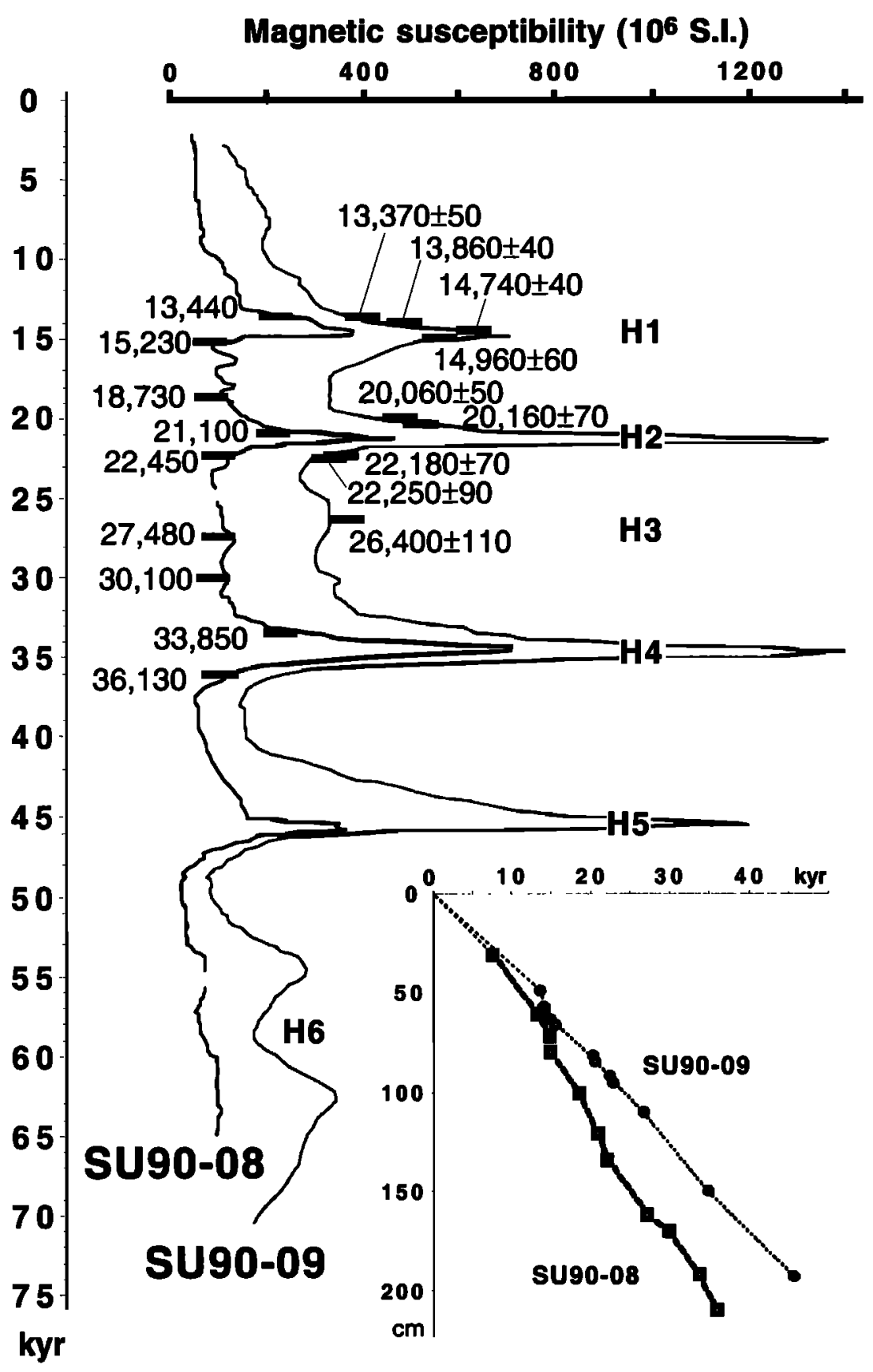

Figure 2: Cores SU90-08 and SU90-09 are located $70 \mathrm{~km}$ from each other, at the same latitude, and can be easily compared. A well constrained timescale has been previously established for core SU90-08 using both the $\delta^{18} \mathrm{O}^{\prime}$ record of planktic foraminifera [Grousset et al., 1993] and 10 accelerator mass spectrometry (AMS) ${ }^{14} \mathrm{C}$ dates. The timescale of core SU90-09 has been derived from the other one by matching the magnetic susceptibility records of both cores, using the Analyseries software [Paillard et al., 1996]. "Typical " Heinrich layers (H1, H2, H4, and H5) are marked by strong, sharp, magnetic susceptibility anomalies, whereas "atypical " Heinrich layers ( $\mathrm{H} 3$ and $\mathrm{H6}$ ) are hardly visible. Nine ${ }^{14} \mathrm{C}$ accelerator mass spectrometry ages obtained on core SU90-09 help to further constrain the timescale. These ages (B.P.) were obtained on foraminifera $N$. pachyderma (left coiling (lc)) $(150-250 \mu \mathrm{m}$ ) and corrected into conventional radiocarbon ages by taking into account ${ }^{13} \mathrm{C} /{ }^{12} \mathrm{C}$ ratios. These ${ }^{14} \mathrm{C}$ ages were finally corrected for a 400 year reservoir age [Bard, 1988]. Error bars are $<100$ years. 


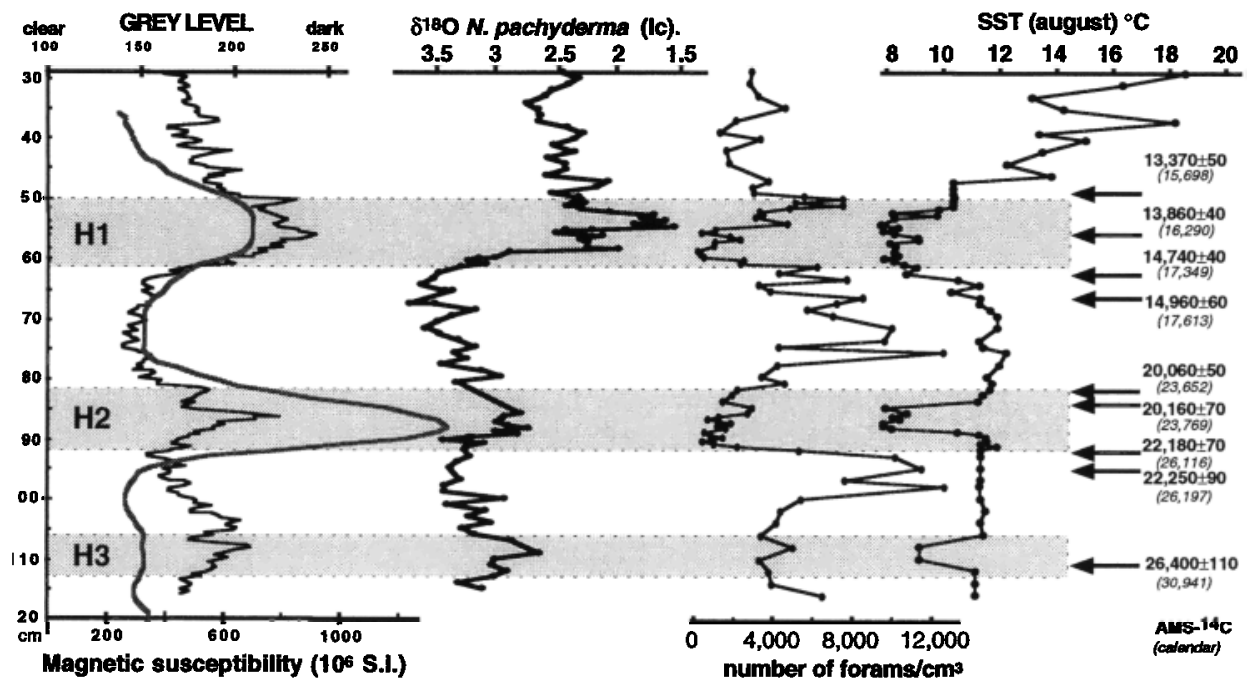

Figure 3. Correlations of magnetic susceptibility and grey level of bulk sediment in core SU90-09, along with the $\delta^{18} \mathrm{O}$ isotopic record, abundance of planktic foraminifers, and summer sea surface temperature (SST) $\left({ }^{\circ} \mathrm{C}\right)$ calculated using the modern analog technique method [Prell, 1985], between 30 and $120 \mathrm{~cm}$. The $\delta^{18} \mathrm{O}$ (normalized to Pee dee belemnite standard) isotopic record is from planktic foraminifera $N$. pachyderma (Ic). Location of Heinrich layers $\mathrm{H} 1, \mathrm{H} 2$, and $\mathrm{H} 3$ is shown by stippled areas. AMS ${ }^{14} \mathrm{C}$ ages are reported along with calendar ages calculated according to Bard [1998].

continents surrounding the northern Atlantic (fjord, estuarine, and continental shelf samples). Because many of the data from the literature deal with a particular rock sample or geological unit, we consider these samples to be less representative of an entire potential source area than are estuarine sediments or adjacent marine sediments, which are derived from a large area. In order to avoid any problem introduced by a possible grainsize fractionation, we have analyzed the same carbonate-free coarse $(>63 \mu \mathrm{m})$ fraction in both the PSA and the core SU9009 samples. It appears that two main domains can be distinguished: first, "field 1 " links the volcanic province (Iceland, Faeroes, or Thulea) to the European province (Scandinavia, British Isles, etc); second, "field 2" links the same volcanic unit to the Canada/Greenland province.

In Figure $6 \mathrm{~b}$ we have plotted the same ratios for all the samples from cores SU90-09. Most of the samples (open circles) fall within field 2 (the Greenland-Canada domain), reflecting the dominance of this source area. A few samples (open crossed circles), corresponding precisely to the volcanic-rich precursor events described above, fall within field 1 (the hyperbolic envelope containing the European domain), and they are close to the Icelandic end-member. We thus consider the Icelandic and the European provinces as the source areas for these specific samples.

\subsection{The $\delta^{13} \mathrm{C}$ and $\delta^{15} \mathrm{~N}$ Composition of Fine-Grained}

\section{(<50 $\mu \mathrm{m})$ Organic Matter}

The $\delta^{13} \mathrm{C}$ and $\delta^{15} \mathrm{~N}$ of organic matter decrease to minimum values of -27.9 and $0.3 \%$ during the phases of enhanced ice rafting corresponding to $\mathrm{H} 1$ and $\mathrm{H} 2$ (Table 4 and Figure 7). These values contrast sharply with those measured for ambient glacial sediments which average $-23.5 \pm 0.7$ and $4.7 \pm 0.9 \%$ for $\delta^{13} \mathrm{C}$ and $\delta^{15} \mathrm{~N}$, respectively $( \pm 1 \sigma)$. No significant deviation from the average values calculated for ambient organic matter is shown by the samples corresponding to $\mathrm{H} 3$ (mean values: $\delta^{13} \mathrm{C}=-23.4 \pm 0.7 \%$ and $\delta^{15} \mathrm{~N}=5.0 \pm 0.4 \%$ ). During $\mathrm{H} 1$ and $\mathrm{H} 2, \delta^{15} \mathrm{~N}$ display high-frequency variations (up to $4 \%$ ), which are not observed for $\delta^{13} \mathrm{C}$, and [TOC] and [TN] contents also display a marked contrast from ambient sedimentary organic matter (mean values $\pm 1 \sigma:[\mathrm{TOC}]=2.95 \pm 0.4 \mathrm{mg} \cdot \mathrm{g}^{-1}$

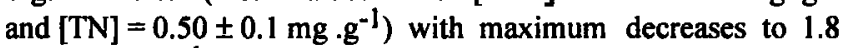
and $0.1 \mathrm{mg} \cdot \mathrm{g}^{-1}$ for TOC and TN, respectively.

\section{Discussion}

Although it seems obvious now that Heinrich events strongly pertubed the thermohaline circulation and, consequently, the climate [Broecker, 1997], the origin of these abrupt climatic events is not fully understood yet. Since the pioneer papers revealing the Heinrich events [Heinrich, 1988; Bond et al., 1992], it has been considered that they were mostly related to surges from the Laurentide ice sheet that occurred during the last glacial period [Broecker, 1994]. Andrews [1998] still considered that the Hudson Strait was the prime source for sediment delivery to the Atlantic during the HLs but clearly stated that abrupt changes in the delivery of IRD were multisourced. It is clear that "typical" HLs (H1, $\mathrm{H} 2, \mathrm{H} 4$, and $\mathrm{H5}$ ) are dominated by Laurentide-derived IRD [Gwiazda et al., 1996a; Hemming et al., 1998], wheras "atypical" HLs (H3 and H6) reflect more complex pan-Atlantic IRD origins [Huon and Jantschik, 1993; Grousset et al., 1993; Gwiazda et al., 1996b; Snoeckx et al., 1999]. Recently, more detailed studies demonstrated that HLs were composed of sublayers originating from different sources. Thus a "precursor" event enriched in volcanic IRD has been identified in some cores from the IRD belt, including ODP-609 and VM 23-81 [Bond and Lotti, 1995; Bond et al., 1999], and in the Irminger Basin, in core SU90-24 [Elliot et al., 1998; Bond et al., 1999] (Figure 1). Along the European margin, similar precursors 
Table 1. Planktic Foraminifer Characteristics: Abundance, $\delta^{18} \mathrm{O}$ of $N$. pachyderma (Ic) and Summer SST

\begin{tabular}{|c|c|c|c|}
\hline Depth cm & $\begin{array}{c}\text { N. pachyderma (lc), } \\
\delta^{18} \mathrm{O}(\% o) \text { PDB }\end{array}$ & $\begin{array}{c}\text { Planktic } \\
\text { Forams per gram }\end{array}$ & $\begin{array}{c}\text { SST } \\
\text { (August), }{ }^{\circ} \mathrm{C}\end{array}$ \\
\hline 30 & 2.45 & 2847 & 18.5 \\
\hline 31 & 2.33 & & \\
\hline 32 & 2.41 & 2748 & 16.3 \\
\hline 33 & 2.54 & & \\
\hline 34 & 2.60 & 3196 & 13.1 \\
\hline 35 & 2.74 & & \\
\hline 36 & 2.66 & 4538 & 14.2 \\
\hline 37 & 2.71 & & \\
\hline 38 & 2.66 & 2039 & 18.2 \\
\hline 39 & 2.43 & & \\
\hline 40 & 2.30 & 1253 & 13.4 \\
\hline 41 & 2.36 & 3282 & 15.0 \\
\hline 42 & 2.53 & & \\
\hline 43 & 2.36 & 1572 & 13.5 \\
\hline 44 & 2.58 & & \\
\hline 45 & 2.45 & 1734 & 12.2 \\
\hline 46 & 2.44 & & 13.8 \\
\hline 47 & 2.60 & 3707 & 10.3 \\
\hline 48 & 2.09 & 2899 & 10.3 \\
\hline 49 & 2.18 & 2963 & 10.3 \\
\hline 50 & 2.54 & 5492 & 10.3 \\
\hline 50.5 & 2.33 & 7422 & 10.3 \\
\hline 51 & 2.31 & 5038 & 10.3 \\
\hline 51.5 & 2.33 & 7422 & 10.3 \\
\hline 52 & 2.38 & 4757 & 9.8 \\
\hline 52.5 & 2.31 & 3264 & 8.2 \\
\hline 53 & 2.08 & 3450 & 9.8 \\
\hline 53.5 & 1.72 & 3020 & 8.2 \\
\hline 54 & 1.79 & 4639 & 7.8 \\
\hline 54.5 & 1.62 & & 8.4 \\
\hline 55 & 1.87 & 1031 & 7.9 \\
\hline 55.5 & 1.55 & 335 & 8.2 \\
\hline 56 & 2.33 & 1754 & 9.1 \\
\hline 56.5 & 2.51 & 2250 & 9.1 \\
\hline 57 & 2.14 & 992 & 8.1 \\
\hline 57.5 & 2.32 & 942 & 8.3 \\
\hline 58 & 2.25 & 128 & 8.2 \\
\hline 58.5 & 2.30 & 303 & 8.4 \\
\hline 59 & 2.01 & 452 & 7.9 \\
\hline 59.5 & 2.89 & 2432 & 8.2 \\
\hline 60 & & 2319 & 8.6 \\
\hline 60.5 & 3.15 & 6153 & 9.1 \\
\hline 61 & 3.23 & 4233 & 8.7 \\
\hline 61.5 & 3.09 & 7654 & 10.5 \\
\hline 62 & 3.29 & 3233 & 11.3 \\
\hline 63 & 3.46 & 3798 & 10.3 \\
\hline 64 & 3.51 & 8461 & 11.3 \\
\hline 65 & 3.61 & 7136 & 11.3 \\
\hline 66 & 3.39 & 5630 & 11.7 \\
\hline 67 & & 6936 & 11.9 \\
\hline 68 & 3.60 & 9913 & 11.9 \\
\hline 69 & 3.16 & 9529 & 11.2 \\
\hline 70 & 3.36 & 4241 & 11.4 \\
\hline 71 & 3.48 & & \\
\hline
\end{tabular}


Table 1 (continued)

\begin{tabular}{|c|c|c|c|}
\hline Depth cm & $\begin{array}{c}\text { N. pachyderma (Ic), } \\
\delta^{18} \mathrm{O}(\%) \text { PDB }\end{array}$ & $\begin{array}{c}\text { Planktic } \\
\text { Forams per gram }\end{array}$ & $\begin{array}{c}\text { SST } \\
\text { (August), }{ }^{\circ} \mathrm{C}\end{array}$ \\
\hline 72 & 3.58 & 12456 & 12.2 \\
\hline 73 & 3.46 & & \\
\hline 74 & 3.31 & 4162 & 12.0 \\
\hline 75 & 3.17 & 3354 & 11.5 \\
\hline 76 & 3.33 & 4540 & 11.7 \\
\hline 77 & 3.24 & & \\
\hline 78 & 3.48 & 2142 & 11.6 \\
\hline 79 & 3.11 & & \\
\hline 80 & 2.96 & 1906 & 11.4 \\
\hline 81 & 3.33 & 1418 & 11.2 \\
\hline 82 & & 2899 & 8.0 \\
\hline 83 & & 2664 & 8.7 \\
\hline 84 & & 1238 & 8.2 \\
\hline 85 & & 653 & 8.5 \\
\hline 86 & 2.79 & 1817 & 7.9 \\
\hline 86.5 & 2.93 & 1131 & 7.9 \\
\hline 87 & 2.95 & 1575 & 8.2 \\
\hline 87.5 & 2.98 & 522 & 10.5 \\
\hline 88 & 2.91 & 803 & 11.3 \\
\hline 88.5 & 2.74 & 1420 & 11.5 \\
\hline 89 & 3.00 & 408 & 11.5 \\
\hline 89.5 & 2.82 & 983 & 11.3 \\
\hline 90 & 3.20 & 2165 & 11.9 \\
\hline 90.5 & 3.43 & 5253 & 11.3 \\
\hline 91 & 3.09 & 10080 & 11.3 \\
\hline 91.5 & 3.24 & 11388 & 11.3 \\
\hline 92 & 3.25 & 7563 & 11.3 \\
\hline 93 & 3.14 & 12534 & 11.3 \\
\hline 94 & 3.31 & & \\
\hline 95 & 3.37 & 5355 & 11.3 \\
\hline \multicolumn{4}{|l|}{96} \\
\hline 97 & 3.28 & 4358 & 11.5 \\
\hline 98 & 3.41 & 4145 & 11.3 \\
\hline 99 & 3.41 & & \\
\hline 100 & 2.93 & 3361 & 11.4 \\
\hline 101 & 3.39 & & \\
\hline 102 & 3.08 & 4957 & 9.2 \\
\hline 103 & 3.21 & & \\
\hline 104 & 3.05 & 3283 & 9.2 \\
\hline 105 & 3.29 & & \\
\hline 106 & 3.17 & 3769 & 11.1 \\
\hline 107 & 2.87 & & \\
\hline 108 & & 3923 & 11.1 \\
\hline 109 & 2.64 & & \\
\hline 110 & 3.00 & 6481 & 11.1 \\
\hline 111 & 3.02 & & \\
\hline 112 & 2.90 & 4393 & \\
\hline 113 & 3.01 & & \\
\hline 114 & 3.30 & 6709 & \\
\hline 115 & 3.10 & & \\
\hline 116 & & 5128 & \\
\hline
\end{tabular}


Table 2. Abundance of Lithic Grains in the Carbonate-Free Coarse $(>150 \mu \mathrm{m})$ Fraction in Core SU90-09

\begin{tabular}{|c|c|c|c|c|}
\hline $\begin{array}{c}\text { Depth, } \\
\text { cm }\end{array}$ & $\begin{array}{c}\text { Lithic, } \\
\text { grains.g-1 }\end{array}$ & $\begin{array}{l}\text { Volcanic, } \\
\text { grains.g-1 }\end{array}$ & $\begin{array}{c}\text { Quartz, } \\
\text { grains.g-1 }\end{array}$ & $\begin{array}{l}\text { Carbonate, } \\
\text { grains.g-1 }\end{array}$ \\
\hline 30 & 81 & 4 & 47 & 9 \\
\hline 31 & 102 & 4 & 55 & 17 \\
\hline 32 & 119 & 13 & 77 & 9 \\
\hline 33 & 98 & 13 & 51 & 4 \\
\hline 34 & 141 & 4 & 85 & 21 \\
\hline 35 & 115 & 9 & 55 & 13 \\
\hline 36 & 222 & 26 & 111 & 30 \\
\hline 37 & 201 & 4 & 145 & 21 \\
\hline 38 & 226 & 9 & 171 & 13 \\
\hline 39 & 329 & 13 & 213 & 34 \\
\hline 40 & 448 & 26 & 303 & 38 \\
\hline 41 & 687 & 43 & 469 & 77 \\
\hline 42 & 828 & 47 & 631 & 68 \\
\hline 43 & 1826 & 102 & 1267 & 183 \\
\hline 44 & 1510 & 132 & 1050 & 102 \\
\hline 45 & 2007 & 79 & 1146 & 523 \\
\hline 46 & 1888 & 77 & 848 & 801 \\
\hline 47 & 2472 & 94 & 1136 & 1001 \\
\hline 48 & 2767 & 90 & 1523 & 794 \\
\hline 49 & 3236 & 128 & 1594 & 1240 \\
\hline 50 & 5857 & 209 & 2716 & 2362 \\
\hline 50.5 & 3392 & 159 & 2182 & 635 \\
\hline 51 & 3066 & 123 & 2081 & 396 \\
\hline 51.5 & 4191 & 189 & 2583 & 896 \\
\hline 52 & 4273 & 168 & 2823 & 891 \\
\hline 52.5 & 5481 & 172 & 2829 & 1833 \\
\hline 53 & 6137 & 110 & 3166 & 2357 \\
\hline 53.5 & 2381 & 98 & 1642 & 282 \\
\hline 54 & 9095 & 222 & 6425 & 1418 \\
\hline 55 & 3641 & 83 & 2379 & 704 \\
\hline 55.5 & 2231 & 134 & 1470 & 347 \\
\hline 56 & 3299 & 129 & 1813 & 1031 \\
\hline 56.5 & 3538 & 106 & 2250 & 743 \\
\hline 57 & 4284 & 140 & 2604 & 1155 \\
\hline 57.5 & 4119 & 131 & 2562 & 936 \\
\hline 58 & 3604 & 137 & 2114 & 813 \\
\hline 58.5 & 6012 & 128 & 2743 & 2433 \\
\hline 59 & 4273 & 111 & 1943 & 1485 \\
\hline 59.5 & 3504 & 127 & 1889 & 935 \\
\hline 60 & 4122 & 178 & 1930 & 1324 \\
\hline 60.5 & 4037 & 234 & 1811 & 1339 \\
\hline 61 & 2922 & 258 & 1360 & 969 \\
\hline 61.5 & 5518 & 272 & 2563 & 2064 \\
\hline 62 & 3262 & 261 & 1434 & 1165 \\
\hline 63 & 3581 & 533 & 1400 & 1107 \\
\hline 64 & 1746 & 235 & 728 & 555 \\
\hline 65 & 1675 & 227 & 783 & 461 \\
\hline 66 & 3008 & 335 & 1408 & 982 \\
\hline 67 & 1212 & 145 & 691 & 235 \\
\hline 68 & 1540 & 128 & 964 & 119 \\
\hline 69 & 1621 & 166 & 1088 & 111 \\
\hline 70 & 862 & 64 & 580 & 85 \\
\hline 71 & 913 & 107 & 640 & 68 \\
\hline
\end{tabular}


Table 2 (continued)

\begin{tabular}{|c|c|c|c|c|}
\hline $\begin{array}{l}\text { Depth, } \\
\text { cm }\end{array}$ & $\begin{array}{c}\text { Lithic, } \\
\text { grains.g-1 }\end{array}$ & $\begin{array}{l}\text { Volcanic, } \\
\text { grains.g-1 }\end{array}$ & $\begin{array}{c}\text { Quartz, } \\
\text { grains.g-1 }\end{array}$ & $\begin{array}{c}\text { Carbonate, } \\
\text { grains.g-1 }\end{array}$ \\
\hline 72 & 1033 & 64 & 661 & 128 \\
\hline 73 & 832 & 55 & 542 & 73 \\
\hline 74 & 789 & 64 & 525 & 51 \\
\hline 75 & 853 & 64 & 572 & 47 \\
\hline 76 & 994 & 68 & 674 & 141 \\
\hline 77 & 909 & 34 & 606 & 141 \\
\hline 78 & 1579 & 90 & 969 & 316 \\
\hline 79 & 2270 & 77 & 1630 & 239 \\
\hline 80 & 2566 & 154 & 1692 & 262 \\
\hline 81 & 3375 & 124 & 1958 & 708 \\
\hline 82 & 4341 & 50 & 1703 & 2224 \\
\hline 83 & 3826 & 59 & 1598 & 1894 \\
\hline 84 & 3980 & 97 & 2043 & 1392 \\
\hline 85 & 7681 & 111 & 2782 & 4326 \\
\hline 86 & 2869 & 99 & 1938 & 416 \\
\hline 86.5 & 3657 & 130 & 2517 & 354 \\
\hline 87 & 3330 & 104 & 2402 & 265 \\
\hline 87.5 & 3321 & 137 & 2127 & 348 \\
\hline 88 & 3819 & 89 & 2682 & 370 \\
\hline 88.5 & 3432 & 138 & 2298 & 346 \\
\hline 89 & 2785 & 109 & 1817 & 280 \\
\hline 89.5 & 3644 & 121 & 1790 & 1235 \\
\hline 90 & 4141 & 108 & 1768 & 1576 \\
\hline 90.5 & 3555 & 196 & 1805 & 968 \\
\hline 91 & 3041 & 199 & 1566 & 813 \\
\hline 91.5 & 2242 & 194 & 1376 & 372 \\
\hline 92 & 3203 & 186 & 1579 & 1045 \\
\hline 93 & 2173 & 273 & 1186 & 425 \\
\hline 94 & 3273 & 280 & 1852 & 749 \\
\hline 95 & 2042 & 214 & 1056 & 559 \\
\hline 96 & 2693 & 229 & 1339 & 760 \\
\hline 97 & 2301 & 202 & 1535 & 268 \\
\hline 98 & 720 & 85 & 301 & 231 \\
\hline 99 & 549 & 58 & 332 & 76 \\
\hline 100 & 695 & 61 & 348 & 204 \\
\hline 101 & 828 & 99 & 479 & 155 \\
\hline 102 & 880 & 131 & 508 & 144 \\
\hline 103 & 1150 & 118 & 686 & 227 \\
\hline 104 & 647 & 74 & 412 & 98 \\
\hline 105 & 902 & 93 & 435 & 269 \\
\hline 106 & 746 & 84 & 449 & 126 \\
\hline 107 & 1281 & 136 & 777 & 205 \\
\hline 108 & 1641 & 150 & 1064 & 248 \\
\hline 109 & 962 & 98 & 544 & 139 \\
\hline 110 & 792 & 50 & 536 & 77 \\
\hline 111 & 565 & 46 & 409 & 43 \\
\hline 112 & 851 & 114 & 491 & 161 \\
\hline 113 & 831 & 104 & 537 & 104 \\
\hline 114 & 955 & 67 & 469 & 316 \\
\hline 115 & 640 & 62 & 407 & 86 \\
\hline 116 & 596 & 55 & 418 & 40 \\
\hline
\end{tabular}




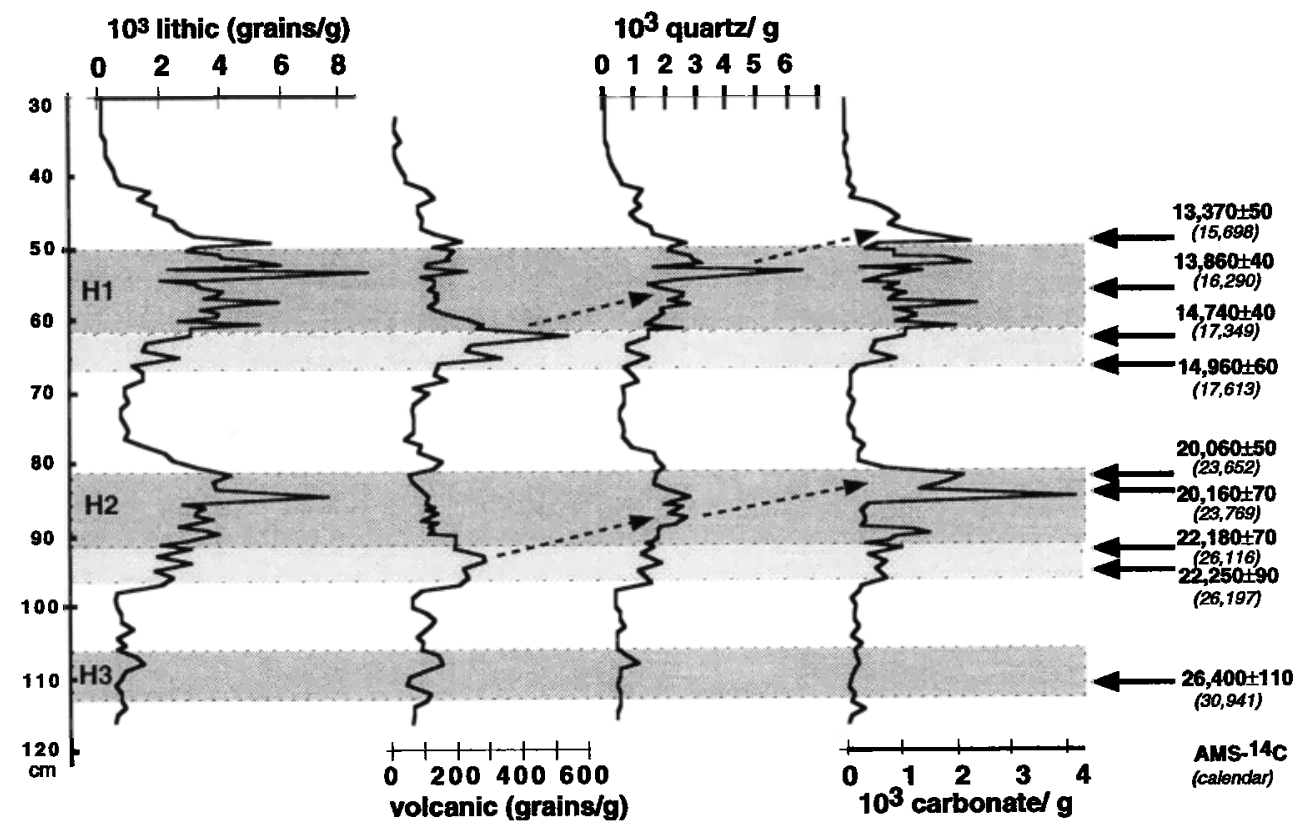

Figure 4. Abundances of lithic grains, detrital carbonate, volcanic glass, and quartz grains in coarse sediments (>150 $\mu \mathrm{m})$ from core SU90-09. Location of Heinrich layers H1, H2, and H3 is shown by stippled areas (light grey band for the European precursors and dark grey band for the Laurentide-derived steps). Arrows emphasize the sequential deposition of (1) volcanic glass, (2) quartz, and (3) detrital carbonate.

made of European continent-derived IRD were recently identified in cores MD95-2002 and SU92-28 [Grousset et al., 2000] (Figure 1). If it can be demonstrated that a sequence of IRD events from different origins can be identified in all HLs, it will tell us more about the timing of the surges (and/or intense iceberg releases) of the different pan-Atlantic ice sheets, and a better understanding of the HL origins could be achieved.

The very high resolution approach that has been conducted on core SU90-09 (every 1-5 centuries) allows us to clearly identify an internal structure (three major steps) of the HLS that is discussed below. Moreover, another mode of variability is superimposed (centennial cycles?) onto this layered structure. Indeed, extremely brief and abrupt events oscillating every $5-10 \mathrm{~mm}$ can be observed on different records: grain counts, $\varepsilon_{\mathrm{Nd}}(0), \delta^{15} \mathrm{~N}$ (Figures 4, 5, and 7). These two modes of variability are addressed now.

\subsection{Sequential Deposition}

A clear petrographic sequence can be identified when looking at the vertical distribution of IRD through the two last HLs (Figure 4). The first step of the IRD increase visible at the beginning of $\mathrm{H} 1$ and $\mathrm{H} 2$ is characterized by a peak of volcanic grains (ashes and basaltic grains), peaking around 22.2 and $14.9 \mathrm{kyr}\left({ }^{14} \mathrm{C}\right)$, respectively. In this core, this first step lasted 1-2 centuries (Figure 4). The $\mathrm{Sr}$ and Nd isotopic composition of these grains was measured in volcanic debris picked from $\mathrm{H1}$. This composition reflects the volcanic source from where they are derived. The following values have been obtained: $\varepsilon_{\mathrm{Nd}}(0)=+7.4$ and ${ }^{87} \mathrm{Sr} /{ }^{86} \mathrm{Sr}=0.703657$ (solid circle in Figure 6a). Such values fit perfectly the composition of the coarse $(>63 \mu \mathrm{m})$ Icelandic basalt debris and volcanic glasses (mean values: $\boldsymbol{\varepsilon}_{\mathrm{Nd}}(0)=+7.6$ and ${ }^{87} \mathrm{Sr} /{ }^{86} \mathrm{Sr}=0.70345$ ). The down core distribution of both ${ }^{87} \mathrm{Sr} /{ }^{86} \mathrm{Sr}$ and $\varepsilon_{\mathrm{Nd}}(0)$ reveals that in both $\mathrm{H} 1$ and $\mathrm{H} 2$ these volcanic-rich precursor events display the same pattern, characterized by a more radiogenic Nd and less radiogenic $\mathrm{Sr}$ (Figure 5). Such an anomaly could be explained by an increase in the proportion of Icelandic glass within the Laurentide-derived IRD. In this case, the isotopic composition of the new mixture would shift within field 2 along hyperbolae linking the Greenland/Canada and the Iceland/Faeroe end-members (Figure 6b). In fact, the isotopic composition of these IRD (open crossed circles) is shifted toward another field of the Sr-Nd plot (field 1), i.e., within the "European-Iceland" isotopic domain, implying that they are made of a complex mixture of European and Icelandic IRD. This is in agreement with the early occurrence of European IRD recognized along the European margins [Grousset et al., 2000]. During HI it is known that the British ice sheet clearly participated in IRD discharges [McCabe and Clark, 1998]. Moreover, European coccoliths were found as far west as the Labrador Sea [Rahman, 1995], and models simulate a possible input of European icebergs in this region [Schäfer-Neth and Statteger, 1997]. Such a structure is also visible in both cores ODP-609 and VM 23-81 [Bond et al., 1999] and can be considered as the volcanic-rich precursor event. During this first step, European icebergs might have followed the same kind of counterclockwise trajectories as the one suggested for atypical events $\mathrm{H} 3$ and $\mathrm{H} 6$ [Grousset et al. 1993].

The second step of the structure is characterized by a strong increase in quartz grains (Figure 4), along with a nonnegligible proportion of various crust-derived minerals (feldspars, micas, and igneous rock debris) and, to a lesser extent, detrital carbonates. It corresponds to the paroxysmal 
Table 3. Sr and Nd Isotopic Composition of the Carbonate-Free Coarse (>63 $\mu \mathrm{m})$ Fraction in Core SU90-09 and in the Pan-Atlantic Possible Source Areas (PSAs)

\begin{tabular}{|c|c|c|c|c|c|}
\hline Core Depth, cm & ${ }^{87} \mathrm{Sr} /{ }^{86} \mathrm{Sr}$ & $\pm 2 \sigma$ & ${ }^{143} \mathrm{Nd} /{ }^{144} \mathrm{Nd}$ & $\pm 2 \sigma$ & $\varepsilon_{\mathrm{Nd}}(\mathbf{0})$ \\
\hline 45 & 0.723949 & 6 & 0511446 & 7 & -23.2 \\
\hline 46 & 0.723734 & 7 & 0.511571 & 5 & -20.8 \\
\hline 47 & 0.723081 & 7 & 0.511310 & 7 & -25.9 \\
\hline 48 & 0.723574 & 8 & 0.511302 & 9 & -26.0 \\
\hline 49 & 0.722207 & 22 & 0511623 & 6 & -19.8 \\
\hline 50 & 0.721503 & 14 & 0.511643 & 5 & -194 \\
\hline 50.5 & 0.717195 & 13 & 0.511493 & 9 & -22.3 \\
\hline 51 & 0.725139 & 9 & 0.511543 & 10 & -21.3 \\
\hline 51.5 & 0.722005 & 12 & 0.511470 & 5 & -22.7 \\
\hline 52 & 0.724049 & 7 & 0.511404 & 9 & -24.0 \\
\hline 52.5 & 0.723493 & 7 & 0.511445 & 7 & -23.2 \\
\hline 53 & 0.722499 & 7 & 0.511419 & 8 & -23.7 \\
\hline 53.5 & 0.719022 & 14 & 0.511190 & 8 & -28.2 \\
\hline 54 & 0.725038 & 8 & 0.511406 & 9 & -24.0 \\
\hline 54.5 & 0.723068 & 9 & 0.511244 & 6 & -27.1 \\
\hline 55 & 0.718776 & 26 & 0.511362 & 10 & -24.9 \\
\hline 55.5 & 0.722482 & 13 & 0.511149 & 6 & -29.0 \\
\hline 56 & & & 0.511346 & 7 & -25.2 \\
\hline 56.5 & 0.723528 & 6 & 0.511068 & 18 & -30.6 \\
\hline 57 & 0.726070 & 10 & 0.510541 & 12 & -40.9 \\
\hline 57.5 & 0.725420 & 7 & 0.511353 & 20 & -25.0 \\
\hline 58 & 0.726622 & 11 & 0.511308 & 34 & -25.9 \\
\hline 58.5 & 0.726567 & 10 & 0.511322 & 14 & -25.6 \\
\hline 59 & 0.722638 & 10 & 0.510686 & 6 & -38.0 \\
\hline 59.5 & 0.720234 & 52 & 0.511367 & 21 & -24.8 \\
\hline 60 & 0.729044 & 20 & 0.511469 & 5 & -22.8 \\
\hline 61 & 0.720395 & 13 & 0.511615 & 9 & -19.9 \\
\hline 61.5 & 0.722103 & 10 & 0511839 & 7 & -15.6 \\
\hline 62 & 0.716033 & 19 & 0.512259 & 3 & -7.4 \\
\hline 63 & 0.718108 & 14 & 0.512341 & 5 & -5.8 \\
\hline 64 & 0.717991 & 6 & 0.512281 & 5 & -6.9 \\
\hline 65 & 0.716623 & 9 & 0.512331 & 5 & -6.0 \\
\hline 66 & 0.719807 & 7 & 0.511700 & 5 & -18.3 \\
\hline 82 & 0.721446 & 6 & 0.511216 & 4 & -27.7 \\
\hline 83 & 0.724295 & 9 & 0.511347 & 5 & -25.1 \\
\hline 84 & & & 0.511103 & 3 & -29.9 \\
\hline 85 & & & 0.511159 & 16 & -28.8 \\
\hline 86 & 0.725306 & 7 & 0.510808 & 16 & -35.7 \\
\hline 86.5 & 0.724431 & 7 & 0.511329 & 13 & -25.5 \\
\hline 87 & 0.722513 & 7 & 0.511269 & 15 & -26.7 \\
\hline 87.5 & 0.728609 & 7 & 0.511074 & 13 & -30.5 \\
\hline 88 & 0.725773 & 6 & 0.510791 & 17 & -36.0 \\
\hline 88.5 & 0.727319 & 6 & 0.511193 & 8 & -28.1 \\
\hline 89 & 0.723157 & 6 & 0.510436 & 5 & -42.9 \\
\hline 89.5 & 0.723311 & 6 & 0.511176 & 9 & -28.5 \\
\hline 90 & 0.723020 & 8 & 0.511161 & 8 & -28.8 \\
\hline 90.5 & 0.722538 & 7 & 0.511165 & 8 & -28.7 \\
\hline 91 & 0.719380 & 8 & 0.511626 & 5 & -19.7 \\
\hline 91.5 & 0.720701 & 7 & 0.511969 & 15 & -13.0 \\
\hline 92 & 0.720522 & 7 & 0.511855 & 6 & -15.2 \\
\hline 93 & 0.717282 & 7 & 0.512085 & 6 & -10.8 \\
\hline 94 & 0.718087 & 6 & 0.511783 & 5 & -16.6 \\
\hline 95 & 0.725986 & 9 & 0.511671 & 4 & -18.8 \\
\hline
\end{tabular}


Table 3. (continued)

\begin{tabular}{|c|c|c|c|c|c|}
\hline Possible Source Areas & ${ }^{87} \mathrm{Sr} /{ }^{86} \mathrm{Sr}$ & $\pm 2 \sigma$ & ${ }^{143} \mathrm{Nd} /{ }^{144} \mathrm{Nd}$ & $\pm 2 \sigma$ & $\varepsilon_{N_{d}}(0)$ \\
\hline Fram Strait & 0.718180 & 37 & 0.511980 & 16 & -12.8 \\
\hline Fram Strait & 0.721620 & 21 & 0.512000 & 15 & -12.4 \\
\hline Vøring Plateau & 0.722900 & & 0.511903 & 12 & -14.3 \\
\hline Vøring Plateau & 0.723500 & & 0.512057 & 11 & -11.3 \\
\hline Oslofjord & 0725039 & 6 & 0.512077 & 8 & -10.9 \\
\hline Sogrefjord & 0.735614 & 6 & 0511923 & 3 & -13.9 \\
\hline Rockall Trough & 0.724352 & 6 & 0512062 & 14 & -11.2 \\
\hline Rockall Trough & 0.724012 & 8 & 0.512001 & 6 & -12.4 \\
\hline Irish Shelf & 0.721308 & 7 & 0511998 & 5 & -12.4 \\
\hline Irish Channel & 0.729787 & 7 & 0512011 & 8 & -12.2 \\
\hline Celtic Sea & 0.720651 & 30 & 0.511965 & 18 & -13.1 \\
\hline British Isles (mean) & 0.732519 & & 0.511966 & & -13.1 \\
\hline Bay of Biscay (mean) & 0730650 & & 0.512030 & & -11.9 \\
\hline SW Portuguese shelf & 0.723874 & 10 & 0.512054 & 6 & -11.4 \\
\hline NW Portuguese shelf & 0.723285 & 9 & 0.511919 & 11 & -14.0 \\
\hline Iceland (mean) & 0703450 & & 0.513924 & & 76 \\
\hline Azores & 0.704172 & 23 & 0.512890 & 16 & 4.9 \\
\hline Faeroe Islands & 0704637 & 11 & 0.512905 & 17 & 5.3 \\
\hline Faeroe Islands & 0.705334 & 29 & 0512966 & 28 & 6.2 \\
\hline Faeroe lslands & 0.703887 & 10 & 0.513037 & 53 & 7.6 \\
\hline Baffin Bay (b) & 0.742870 & & & & -33.0 \\
\hline Baffin Bay (b) & 0.731560 & & & & -27.4 \\
\hline Saint Lawrence & 0.720113 & 8 & 0.511738 & 5 & -17.5 \\
\hline Milnes Seamount & 0728360 & 12 & 0510991 & 11 & -32.1 \\
\hline GRIP bedrock & 0728800 & 11 & 0.510403 & 20 & -43.5 \\
\hline GRIP bedrock & 0.731670 & 7 & 0.510739 & 12 & -370 \\
\hline East Greenland shelf & 0.713495 & 8 & 0.512094 & 9 & -10.6 \\
\hline Farewell Cape & 0.711110 & 10 & 0.511483 & 12 & -22.5 \\
\hline
\end{tabular}

a Location given on Figure 1 as solid squares

b Goldstein and Jacobsen [1988]

input of IRD during the Heinrich events, as reflected by the sudden dilution of the planktic foraminifers, the lightening of $\delta^{18} \mathrm{O}$ of $N$. pachyderma (lc), a $3^{\circ} \mathrm{C}$ surface water cooling and a $\approx 2 \%$ SSS decrease, comparable to the estimation obtained for H4 in the twin core SU90-08 [Cortijo et al, 1997].

The $\mathrm{Sr}$ and Nd isotopic composition was measured in quartz grains picked from $\mathrm{H} 1$ under the binocular microscope. This composition must reflect the continental source from when they were eroded by ice sheets. Their isotopic composition $\left(\varepsilon_{\mathrm{Nd}}(0)=-26\right.$ and $\left.{ }^{87} \mathrm{Sr} /{ }^{86} \mathrm{Sr}=0.721341\right)$ falls right in the middle of the Greenland/Canada field (solid square in Figure $6 \mathrm{~b}$ ), and is very similar to most of the $\mathrm{H} 1$ and $\mathrm{H} 2$ samples (open circles on Figure 6b). During this second step the isotopic evolution with time is significantly variable (Figure 5), with $E_{\mathrm{Nd}}(0)$ fluctuating between -20 and -45 . Despite the presence of negligible Paleozoic outcrops located in northwestem Scotland, the majority of the British Isles outcrops display much more radiogenic $\varepsilon_{\mathrm{Nd}}(\mathrm{o})$ ranging between -9 and -14 [Miller and $O^{\prime}$ Nions, 1984; this study]. These latter values are consistent with the composition of the coarse $(>63 \mu \mathrm{m})$ fraction of the British Isles continental shelf sediments (Table 3 and Figure 6a). Moreover, the Fennoscandian ice sheet eroded the old crustal Baltic shield. Quite unradiogenic $\varepsilon_{\mathrm{Nd}}(0)$ values were reported from the Baltic region [Miller and O'Nions, 1985], but they were obtained on bulk rocks. The isotopic composition of the coarse $(>63 \mu \mathrm{m})$ fraction of the Scandinavian shelf/fjord sediments (Table 3 and Figure 6a) reveals, indeed, much more radiogenic $\mathrm{Nd}\left(-14<\varepsilon_{\mathrm{Nd}}(0)<-11\right)$, similar to the British Isles signature. Thus a potential contribution of both the Fennoscandian and British Isles ice sheets would not explain the unradiogenic values observed during the second step $\left(-20>\varepsilon_{N d}(0)>-45\right)$. Finally, such negative $\varepsilon_{N d}(0)$ is characteristic of the Labrador Sea, the Bay of Baffin, across the Canadian shield and Greenland [McCulloch and Wasserburg, 1978; Goldstein and Jacobsen, 1988], and thus step 2 would correspond to the paroxysmal step of the Laurentide surge.

The third step is characterized by an input of dominant detrital carbonate, while crust-derived grains and volcanic glass were disappearing. It is known that the northern Canadian provinces (Ellesmere Islands, Banks and Victoria Islands, and Mackenzie basin) are dominated by limestones [Bischof and Darby, 1997]. Bond et al. [1992] suggested that these Paleozoic limestones surrounding the northern part of Baffin Bay and Hudson Bay were the main source of detrital carbonate. Consistently, detrital carbonate is abundant in the HLs from the Labrador Sea-Hudson Bay [Andrews and Tedesco, 1992]. The Baffin Bay area has also been proposed as a possible source area [Dowdeswell et al., 1995]. In order to check this hypothesis, the $\mathrm{Sr}-\mathrm{Nd}$ isotopic composition was measured in detrital carbonate grains picked up within H1. Their composition should reflect the sea water composition that characterized the ocean, at the time of the parent limestone deposition. The following values were obtained: $\varepsilon_{\mathrm{Nd}}(0)=$ 


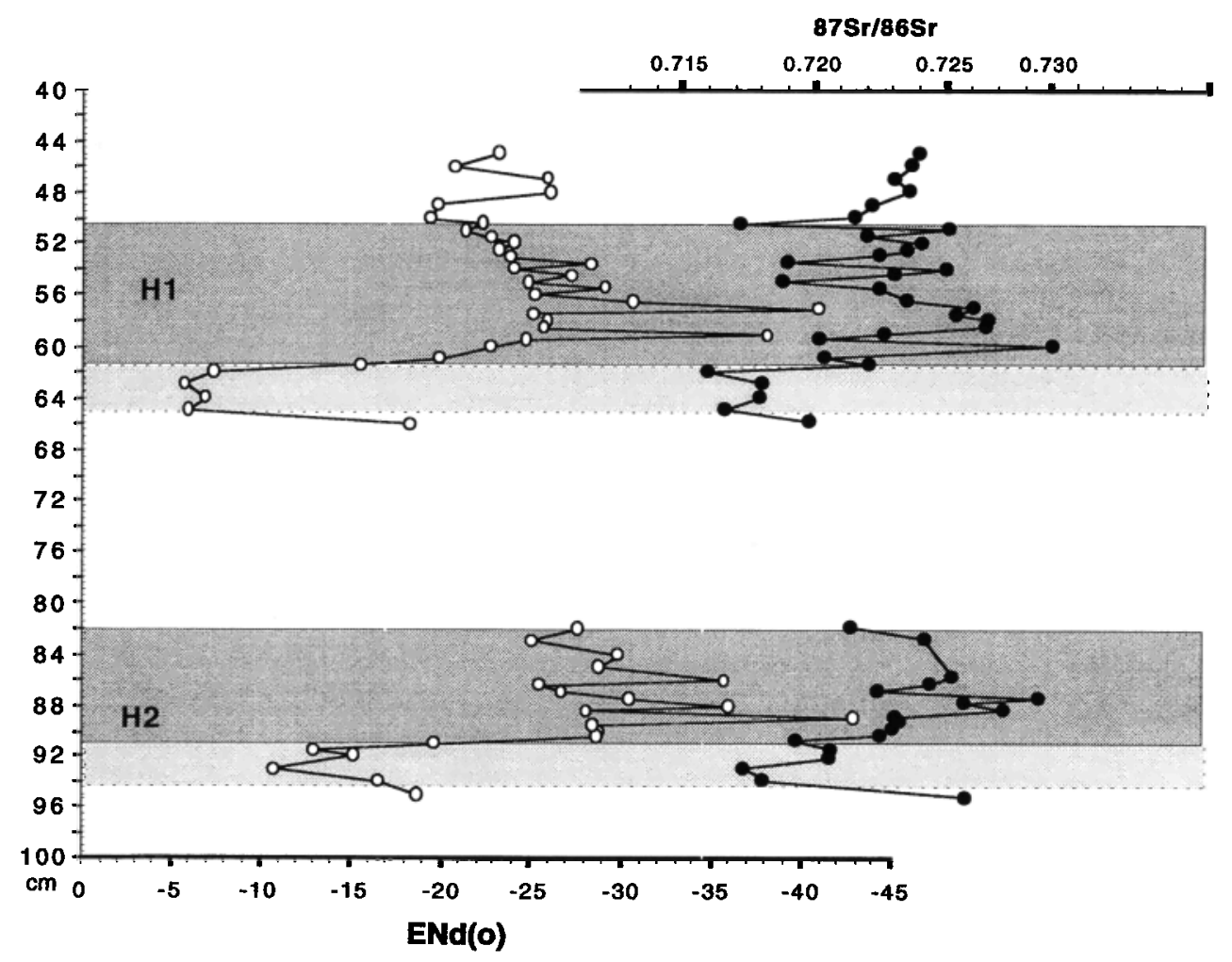

\begin{abstract}
Figure 5. Correlation of ${ }^{87} \mathrm{Sr} /{ }^{86} \mathrm{Sr}$ with ${ }^{143} \mathrm{Nd} /{ }^{144} \mathrm{Nd}$ isotopic ratıos of the coarse $(>63 \mu \mathrm{m})$, carbonate-free IRD fraction. The ${ }^{143} \mathrm{Nd} /{ }^{144} \mathrm{Nd}$ ratios are expressed as as $\varepsilon N d(0)$. Error bars are smaller than symbols. Samples are analyzed every centimeter between the HLs and every $5 \mathrm{~mm}$ within $\mathrm{Hl}$ and H2. Location of Heinrich layers H1and H2 is shown by stippled areas, dark grey for the Laurentide events and light grey for the European precursor events.
\end{abstract}

-16.8 and ${ }^{87} \mathrm{Sr} /{ }^{86} \mathrm{Sr}=0.708414$. In the North Atlantic region, such a negative $\varepsilon_{\mathrm{Nd}}(0)$ value is traced to the Labrador SeaBaffin Bay area, where the modern sea-water imprint ranges from -16 down to -27 [Stordal and Wasserburg, 1986]. These values result from the weathering of the surrounding Archean cratonic blocks as well as the lower Paleozoic carbonate rocks that are abundant in the northern Baffin Bay and the Hudson Bay areas. Concerning the ${ }^{87} \mathrm{Sr} /{ }^{86} \mathrm{Sr}$ composition of these carbonate grains, the ${ }^{87} \mathrm{Sr} /{ }^{86} \mathrm{Sr}$ ratio $(0.708414)$ strongly differs from the one that characterizes the recent seawater composition $\left({ }^{87} \mathrm{Sr} /{ }^{86} \mathrm{Sr}=0.7092\right)$. Such a low value is only observed during a short period of the lower Miocene and during the entire Paleozoic period [Elderfield, 1986]. As there is no Miocene formation in the northeastern Canada/Greenland area, this signature can only reflect a Paleozoic origin, which is consistent with the $\mathrm{Nd}$ fingerprint and definitely confirms the "Baffin/Labrador" origin of the carbonate grains observed in the HLs. Such a low ratio $(\approx 0.7084)$ is not specific to $\mathrm{Hl}$. We also found it in $\mathrm{H} 4$ from core M6-7A-244/1 [Heinrich, 1988] (Figure 1) $\left({ }^{87} \mathrm{Sr} /{ }^{86} \mathrm{Sr}=0.70865\right)$, reflecting the strong influence of detrital Paleozoic carbonate. On the contrary, the ambient (non-HL) sediment is dominated by the glacial plankton carbonate, displaying an isotopic composition $\left.{ }^{87} \mathrm{Sr} /{ }^{86} \mathrm{Sr}=0.70902\right)$ close to the last glacial seawater value ${ }^{87} \mathrm{Sr} /{ }^{86} \mathrm{Sr}=0.7092$ ).

This three-step sequence is observed in both $\mathrm{H} 1$ and $\mathrm{H} 2$ and may be characteristic of the HL genesis. A similar sequence is also visible in other parts of the IRD belt, for example, in core VM23-81 (Figure 1), especially during $\mathrm{H} 2$ [Bond and Lotti, 1995]. This structure reflects changes in the source of icebergs released in the ocean during a Heinrich event. Icebergs were first released by the European ice sheets (Iceland, British Isles, and Fennoscandia) during a precursor event, followed then by the Laurentide surge.

It seems that during the precursor event, icebergs were released roughly simultaneously by the different European ice sheets. Indeed, before $\mathrm{H} 2$, the Icelandic event started just before $22.2 \mathrm{kyr}$ B.P. in core SU90-09 (Figure 3), around 22.0 and $22.4 \mathrm{kyr}$ B.P. in cores VM23-81 and ODP 609, respectively [Bond et al., 1999]. At the same time, the European (British ice sheet IRD) event started along the Celtic margin at $21.85 \mathrm{kyr}$ B.P. in core MD95-2002 [Grousset et al., 2000] and at $22.1 \mathrm{kyr}$ B.P. in core OMEX-2K [Scourse et al., 2000]. Surprisingly, Bischof and Darby [1997, 1999] reported that simultaneously the Innuitian ice sheet released its first icebergs in the Arctic area $\sim 1.5 \mathrm{kyr}$ before the Laurentide surge. This early initiation is almost synchronous with the appearance of the atmospheric $\mathrm{H} 2$ equivalent observed in the Greenland Ice Sheet Project 2 (GISP2) ice core [Mayewski et al., 1994]. In the same way, before HI, the Icelandic event started around $15 \mathrm{kyr}$ B.P. in cores SU90-09 (Figure 3), VM 23-81 and Ocean Drilling Program (ODP) 609 [Bond et al., 1999]. This synchronicity hypothesis challenges the vision proposed by Dowdeswell et al. [1999], who 

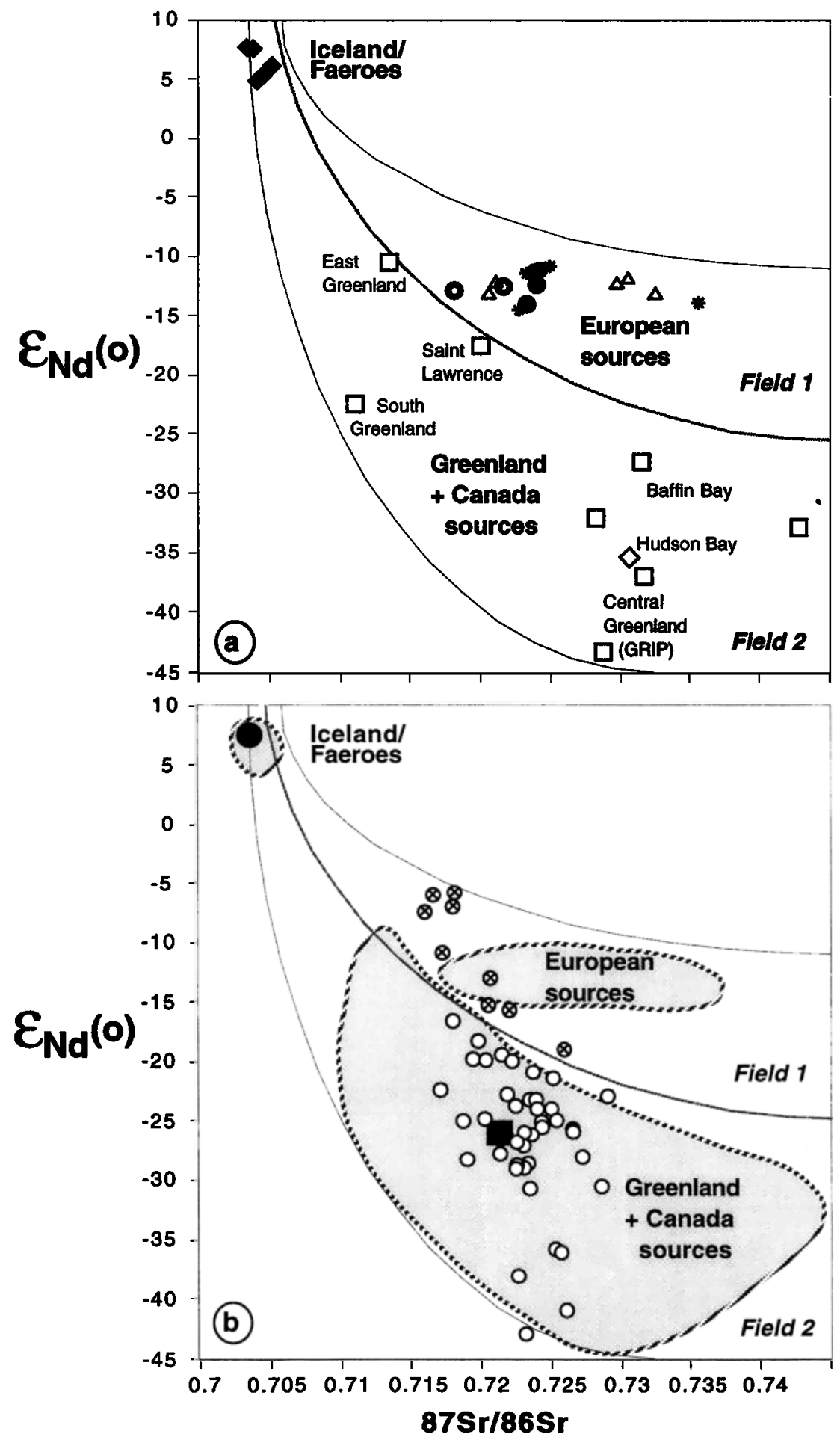

Figure $6 .{ }^{87} \mathrm{Sr} /{ }^{86} \mathrm{Sr}$ ratios versus ${ }^{143} \mathrm{Nd} /{ }^{144} \mathrm{Nd}$ ratios, expressed as $\varepsilon \mathrm{Nd}(0)$. These data were obtained on the coarse (>63 $\mu \mathrm{m})$, carbonate-free fraction on both the core SU90-09 samples and the potential source area (PSA) samples. Error bars are smaller than symbols. (a) The PSA are reported as large solid dianionds (volcanic provinces), open triangles (British Isles sources), stars (Scandinavian sources), closed circles (other European sources), and open squares (North American sources), and their envelopes are contoured by hand, roughly following mixing hyperbolae. The precise location of each PSA sample is provided on Figure 1. Despite the fact that they are bulk samples (as opposed to the other coarse fractions), present-day samples of suspended particulate matter from the Hudson Bay [Goldstein and Jacobsen, 1988] and from the Fram Strait (open circles and open diamond, respectively) are also plotted for comparison. (b) Samples for core SU90-09 (open circles) are represented along with the envelopes of the main source provinces (stippled areas). Volcanic glasses and quartz grains picked from within the European precursor of $\mathrm{Hl}$ (level $93 \mathrm{~cm}$ ) are also plotted (solid circle and solid square, respectively). 
Table 4. $C$ and $N$ Abundance and Isotopic Composition of the Carbonate-Free Fine $(<50 \mu \mathrm{m})$ Fraction

\begin{tabular}{|c|c|c|c|c|c|}
\hline Depth, cm & $\begin{array}{c}\mathrm{OC} \\
\left(\mathrm{mg} \cdot \mathrm{g}^{-1}\right)\end{array}$ & $\begin{array}{c}\mathrm{TN} \\
\left(\mathrm{mg} \cdot \mathrm{g}^{-1}\right)\end{array}$ & $\begin{array}{c}\mathrm{OC} / \mathrm{TN} \\
(\mathrm{C} / \mathrm{N}) \\
\end{array}$ & $\begin{array}{c}\delta^{13} \mathrm{C} \text { vs PDB, } \\
\% \\
\end{array}$ & $\begin{array}{c}\delta^{15} \mathrm{~N} \text { vs Alr, } \\
\%_{0}\end{array}$ \\
\hline 40 & 3.87 & 0.48 & 8.06 & -21.9 & 5.41 \\
\hline 41 & 4.03 & 0.56 & 7.2 & -22.46 & 5.33 \\
\hline 42 & 3.77 & 0.55 & 6.85 & -22.67 & 6.29 \\
\hline 43 & 3.87 & 0.58 & 6.67 & -22.84 & 4.27 \\
\hline 44 & 4.0 & 0.54 & 7.41 & -22.36 & 5.42 \\
\hline 45 & 3.8 & 0.52 & 7.31 & -22.24 & 4.33 \\
\hline 46 & 3.97 & 0.55 & 7.22 & -22.2 & 6.33 \\
\hline 47 & 4.05 & 0.51 & 7.95 & -23.64 & 5.29 \\
\hline 49 & 3.87 & 0.58 & 6.67 & -23.44 & 4.27 \\
\hline 50 & 3.23 & 0.41 & 7.88 & -24.88 & 5.18 \\
\hline 50.5 & 3.21 & 0.38 & 8.45 & -25.3 & 4.5 \\
\hline 51 & 3.0 & 0.36 & 8.33 & -25.86 & 4.36 \\
\hline 51.5 & 3.13 & 0.46 & 6.8 & -24.98 & 4.09 \\
\hline 52 & 2.81 & 0.37 & 7.59 & -25.67 & 3.93 \\
\hline 52.5 & 2.72 & 0.32 & 8.5 & -26.25 & 3.97 \\
\hline 53 & 2.93 & 0.33 & 8.88 & -27.02 & 4.35 \\
\hline 53.5 & 2.63 & 0.28 & 9.39 & -27.27 & 4.09 \\
\hline 54 & 2.79 & 0.32 & 8.72 & -26.68 & 4.63 \\
\hline 54.5 & 2.51 & 0.28 & 8.96 & -26.78 & 4.62 \\
\hline 55 & 2.46 & 0.24 & 10.25 & -27.37 & 3.27 \\
\hline 55.5 & 2.31 & 0.24 & 9.62 & -27.43 & 4.0 \\
\hline 56 & 2.83 & 0.29 & 9.76 & -27.64 & 2.72 \\
\hline 56.5 & 2.8 & 0.24 & 11.67 & -27.76 & 3.18 \\
\hline 57 & 2.8 & 0.24 & 11.67 & -27.69 & 2.15 \\
\hline 57.5 & 2.87 & 0.27 & 10.63 & -27.49 & 2.08 \\
\hline 58 & 2.72 & 0.23 & 11.83 & -27.2 & 1.58 \\
\hline 58.5 & 2.78 & 0.22 & 12.64 & -27.99 & 1.96 \\
\hline 59 & 2.56 & 0.3 & 8.53 & -27.24 & 3.21 \\
\hline 59.5 & 2.96 & 0.34 & 8.71 & -27.3 & 3.4 \\
\hline 60 & 3.4 & 0.39 & 872 & -26.57 & 3.63 \\
\hline 60.5 & 2.89 & 0.34 & 8.5 & -26.55 & 4.4 \\
\hline 61 & 2.91 & 0.34 & 8.56 & -26.68 & 3.5 \\
\hline 61.5 & 3.05 & 0.42 & 7.26 & -25.81 & 4.13 \\
\hline 62 & 3.03 & 0.42 & 7.21 & -24.8 & 4.5 \\
\hline 63 & 3.22 & 0.51 & 6.31 & -24.42 & 5.24 \\
\hline 64 & 3.54 & 0.56 & 6.32 & -24.56 & 4.62 \\
\hline 65 & 3.62 & 0.52 & 6.96 & -24.3 & $\$ .4$ \\
\hline 66 & 3.61 & 0.51 & 7.08 & -24.47 & 6.11 \\
\hline 67 & 3.05 & 0.51 & 5.98 & -23.41 & 5.22 \\
\hline 68 & 3.62 & 0.51 & 7.1 & -24.48 & 5.47 \\
\hline 69 & 3.53 & 0.62 & 5.69 & -23.48 & 4.94 \\
\hline 70 & 4.1 & 0.61 & 6.72 & -23.72 & 5.83 \\
\hline 71 & 3.95 & 0.61 & 6.48 & -23.71 & 5.48 \\
\hline 72 & 3.94 & 0.55 & 7.16 & -23.6 & 5.7 \\
\hline 73 & 3.56 & 0.61 & 5.84 & -23.18 & 5.22 \\
\hline 74 & 3.41 & 0.57 & 5.98 & -22.89 & 6.51 \\
\hline 75 & 4.56 & 0.59 & 7.73 & -23.2 & 6.49 \\
\hline 76 & 4.4 & 0.62 & 7.1 & -23.14 & 6.38 \\
\hline 77 & 3.86 & 0.63 & 6.13 & -23.47 & 4.94 \\
\hline 78 & 3.42 & 0.6 & 5.7 & -24.69 & 4.89 \\
\hline 79 & 3.55 & 0.57 & 6.23 & -24.9 & 4.64 \\
\hline 80 & 3.62 & 0.52 & 6.96 & -24.5 & 6.03 \\
\hline 81 & 3.85 & 0.5 & 7.7 & -25.2 & 5.03 \\
\hline 82 & 3.6 & 0.46 & 7.83 & -25.04 & 5.87 \\
\hline 83 & 2.92 & 0.41 & 7.12 & -25.39 & 3.45 \\
\hline 84 & 3.36 & 0.41 & 8.2 & -26.18 & 3.74 \\
\hline 85 & 3.03 & 0.29 & 10.45 & -27.36 & 4.24 \\
\hline
\end{tabular}


Table 4. (continued)

\begin{tabular}{|c|c|c|c|c|c|}
\hline Depth, cm & $\begin{array}{c}\mathrm{OC} \\
\left(\mathrm{mg} \cdot \mathrm{g}^{-1}\right)\end{array}$ & $\begin{array}{c}\text { TN } \\
\left.\text { (mg } \cdot g^{-1}\right)\end{array}$ & $\begin{array}{l}\text { OC/TN } \\
(\mathrm{C} / \mathrm{N})\end{array}$ & $\begin{array}{c}\delta^{\prime \prime} \mathrm{C} \text { vs PDB, } \\
\%_{\theta}\end{array}$ & $\begin{array}{c}\delta^{15} \mathrm{~N} \text { vs Air, } \\
\%\end{array}$ \\
\hline 86 & 3.08 & 0.29 & 10.62 & -27.11 & 2.51 \\
\hline 86.5 & 2.8 & 0.3 & 9.33 & -27.4 & 4.27 \\
\hline 87 & 2.65 & 0.27 & 9.81 & -27.41 & 3.09 \\
\hline 87.5 & 3.53 & 0.33 & 10.7 & -28.03 & 3.05 \\
\hline 88 & 3.37 & 0.31 & 10.87 & -27.67 & 3.07 \\
\hline 88.5 & 2.76 & 0.28 & 9.86 & -27.34 & 2.18 \\
\hline 89 & 3.05 & 0.27 & 11.3 & -27.65 & 3.17 \\
\hline 89.5 & 3.4 & 0.34 & 10.0 & -26.91 & 3.34 \\
\hline 90 & 4.24 & 0.34 & 12.47 & -27.0 & 4.42 \\
\hline 90.5 & 4.19 & 0.38 & 11.03 & -27.0 & 2.87 \\
\hline 91 & 3.86 & 0.47 & 8.21 & -25.58 & 4.88 \\
\hline 91.5 & 3.93 & 0.57 & 6.89 & -24.23 & 5.4 \\
\hline 92 & 4.45 & 0.73 & 6.1 & -24.16 & 5.87 \\
\hline 93 & 3.79 & 0.59 & 6.42 & -23.4 & 5.2 \\
\hline 94 & 4.1 & 0.57 & 7.19 & -24.61 & 5.8 \\
\hline 95 & 4.13 & 0.6 & 6.88 & -24.73 & 4.99 \\
\hline 96 & 3.92 & 0.5 & 7.84 & -25.34 & 5.31 \\
\hline 97 & 3.1 & 0.52 & 5.96 & -23.16 & 5.99 \\
\hline 98 & 3.73 & 0.69 & 5.41 & -22.47 & 6.21 \\
\hline 99 & 3.12 & 0.53 & 5.89 & -22.8 & 5.34 \\
\hline 100 & 3.3 & 0.63 & 5.24 & -22.74 & 5.86 \\
\hline 101 & 3.22 & 0.59 & 5.46 & -22.9 & 5.34 \\
\hline 102 & 3.22 & 0.53 & 6.08 & -23.57 & 4.99 \\
\hline 103 & 3.49 & 0.6 & 5.82 & -23.37 & 6.16 \\
\hline 104 & 3.28 & 0.62 & 5.29 & -22.98 & 5.82 \\
\hline 105 & 3.14 & 0.58 & 5.41 & -23.57 & 6.05 \\
\hline 106 & 3.1 & 0.6 & 5.17 & -24.1 & 5.86 \\
\hline 107 & 3.1 & 0.6 & 5.17 & -23.0 & 5.94 \\
\hline 108 & 3.24 & 0.55 & 5.89 & -23.34 & 5.18 \\
\hline 109 & 3.23 & 0.5 & 6.46 & -24.89 & 5.08 \\
\hline 110 & 3.15 & 0.49 & 6.43 & -24.65 & 5.82 \\
\hline 111 & 3.21 & 0.56 & 5.73 & -23.31 & 5.17 \\
\hline 112 & 3.66 & 0.59 & 6.2 & -23.65 & 5.48 \\
\hline 113 & 3.2 & 0.5 & 6.4 & -23.3 & 5.36 \\
\hline 114 & 3.2 & 0.6 & 5.33 & -22.5 & 5.86 \\
\hline 115 & 3.29 & 0.55 & 5.98 & -22.92 & 5.06 \\
\hline
\end{tabular}

Here vs is versus

considered that deposition of IRD in the Nordic Seas and the North Atlantic Ocean were asynchronous. We do not think, however, that this is contradictory, as their conclusion is based on a low-resolution study of cores, for which a limited number of ${ }^{14} \mathrm{C}$ ages is provided, thus limiting the control on their timescales. On the contrary, the synchronicity hypothesis is consolidated by consistent observations made in both the Norwegian Sea and the Irminger Basin [M. Elliot et al., manuscript in preparation, 2001].

Along the European margin, the second step (Laurentidederived IRD) started around $20.4 \mathrm{kyr}$ B.P in core OMEX-2K [Scourse et al., 2000], at $\sim 20.2 \mathrm{kyr}$ B.P. in core MD95-2002 [Grousset et al., 2000], and 20.5 kyr B.P. in core SO75-26KL [Zahn et al., 1997]. These remote areas were probably reached only by the paroxysmal, late pulse of the Laurentide surge, whereas earlier Laurentide-derived IRD reached the axial part of the IRD belt (core VM23-81) around $21.5 \mathrm{kyr}$ B.P. [Bond et al., 1999]. These Laurentide-derived IRD are made of rock fragments, quartz, and micas, all these minerals being derived from the erosion of the crustal rocks forming the Canadian shield. They accompany detrital carbonate coming from the Hudson and northern Baffin Bays.

The third step is dominated by detrital carbonate coming from these nortwestern regions. These two last steps imply some change may be related to the evolving shape of the Laurentide ice sheet during its surge. The Laurentide ice sheet would have first scraped old crustal formations occurring mostly along the rims of the ice sheet; then, after the major collapse of this ice sheet, icebergs more likely carrying detrital carbonate would come from the central part of the ice sheet (Hudson and northern Baffin Bays).

According to Alley [1998], this sequence of the Heinrich events challenges the idea of a global forcing triggering the HLs. Other processes, such as change in the thermohaline patterns and or destabilization of ice sheet rims were involved, probably implying a multistep story as proposed by Scourse et al. [2000]. As already hypothetized, whether or not these precursor events could be associated to the millenial-scale (12 kyr) Dansgaard-Oeschger cycles [Grousset et al., 2000] remains an open question, challenged by other interpretations 


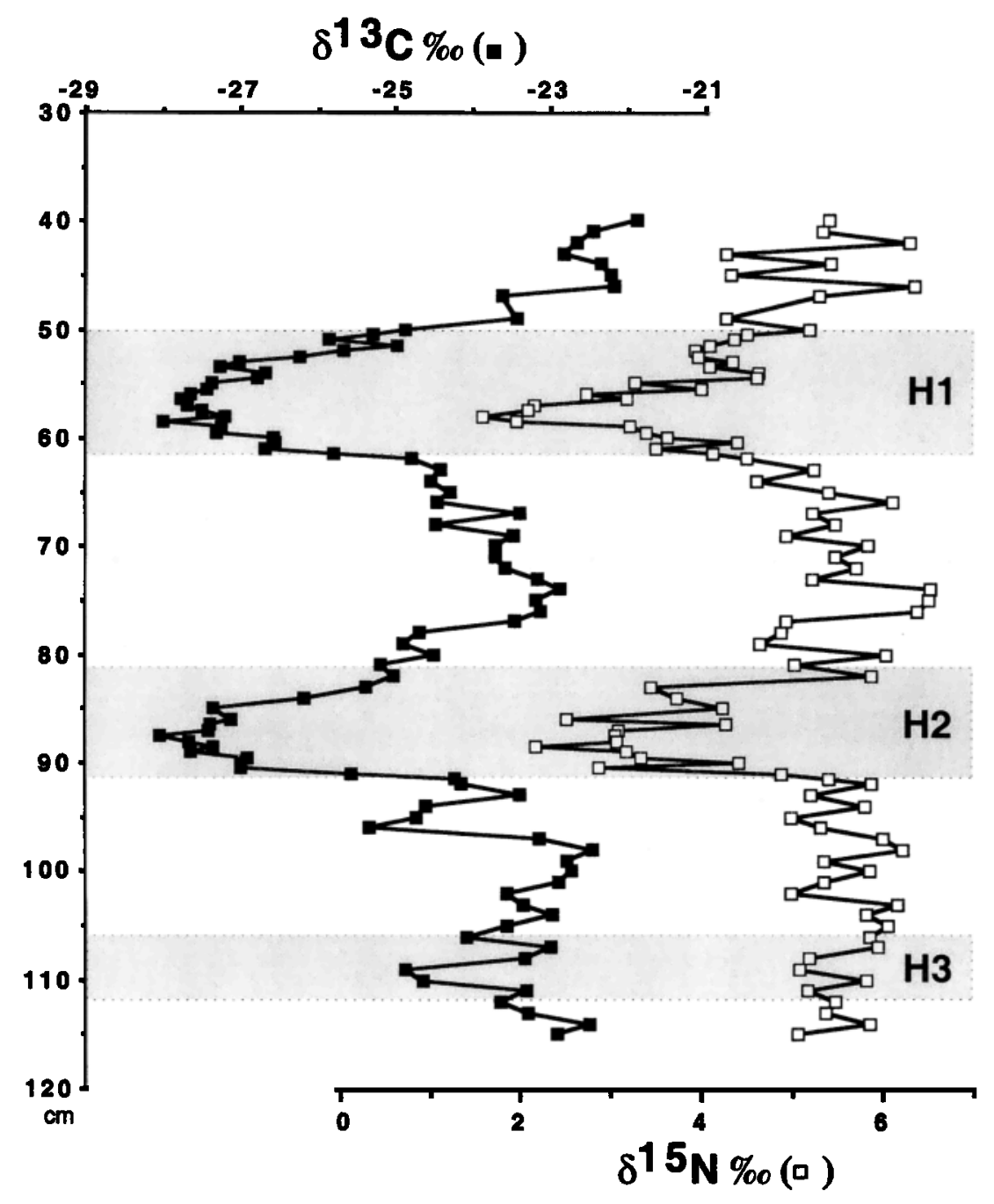

Figure 7. Down core variations in the organic matter composition $\left(\delta^{13} \mathrm{C}\right.$ are solid squares, and $\delta^{15} \mathrm{~N}$ are open squares) of the fine $(<50 \mu \mathrm{m})$ carbonate-free fraction across $\mathrm{HI}, \mathrm{H} 2$, and $\mathrm{H} 3$ in core SU90-09. Location of Heinrich layers $\mathrm{H1}, \mathrm{H} 2$ and $\mathrm{H3}$ is shown by stippled areas.

[Alley and MacAyeal, 1994; Broecker, 1997; Bond et al., 1999; Scourse et al., 2000]. According to Scourse et al. [2000] and Knutz et al., [2001], some other forcing factors must have caused changes in thermocline circulation patterns, which may have triggered the Laurentide collapses. Thus the relationship linking the different ice sheet disequilibria could involve complex feedbacks between sealevel changes, ice sheet dynamics, and variation in the northward heat/moisture transport by the thermohaline circulation.

\subsection{High Frequency ( $\approx$ Centennial) Pulses}

Cyclic, abrupt oscillations are visible within the HLs. This high-frequency variability is reflected by three independant records: the amount of coarse grains (Figure 4), their $\mathrm{Sr}-\mathrm{Nd}$ composition (Figure 5) and the organic matter composition (Figure 7). For example, about four to six short oscillations occurred during $\mathrm{Hl}$ and about four occurred during $\mathrm{H} 2$. Considering the duration of Heinrich events, these oscillations would have occurred on a timescale of 2-5 centuries. As revealed by $\mathrm{X}$-ray imagery, these pulses are separated by horizontal, thin ( $\leqslant 5 \mathrm{~mm}$ thick) laminations of fine deposits, similar to ambient glacial sediments that were deposited between HLs. Such a fine-scale structure could reflect oscillations in the Laurentide iceberg delivery. This pulsed surge hypothesis would have to be tested by models in order to see if it is consistent with the ice sheet dynamics. Exactly the same structure has been described for $\mathrm{Hl}$ in core DAPC-2 (Figure 1) [Knutz et al., 2001]. This observation implies that both the Laurentide and the British ice sheets released their icebergs on a similarly pulsed mode. Knutz et al. [2001] suggest that these centennial-scale IRD peaks could correspond to grounding adjustments of the British ice sheet inflicted by a steady rise sea level. This process cannot explain, however, the similar structure observed in core SU9009 during $\mathrm{H} 2$, which implies that more regional changes may have been involved. Another explanation might be the northsouth oscillation of the location of the pathway of detritusladen icebergs, the so-called IRD belt. Ruddiman [1977] originally determined its mean location by averaging the 
entire glacial period. In fact, more detailed analysis reveals that for example, the main axis of the IRD belt was centered around $45^{\circ} \mathrm{N}$ during $\mathrm{H} 2$ but was shifted northward up to $47^{\circ} \mathrm{N}$ during H5 [Grousset et al., 1993]. Such latitudinal oscillations could have generated the observed records. These pulses could be induced by short-term latitudinal shifts of the boundary separating the northern Atlantic cyclonic gyre and the restricted polar clockwise penetration of the North Atlantic drift [Keffer et al., 1988; Chapman and Maslin, 1999]. Core SU90-09, being located at the southern boundary of the IRD belt, could have been impacted intermittently by the rain of IRD. These hypotheses could be checked by looking at cores located in the center of the IRD belt, where they would have been insensitive to slight latitudinal shifts. Unfortunately, studies already published on such cores were conducted at a lower resolution, and these cores should be revisited at a similar ultrahigh-resolution mode as that used for core SU9009.

\subsection{Continental Versus Marine Sources of Organic Matter}

\section{Within the HLs}

We can make the asumption that marine organic matter originating from cold areas of high latitudes regions represent possible sources of organic matter to deep-sea sediments of the NE Atlantic during Heinrich events. However, their isotopic values generally do not match those measured for $\mathrm{H} 1$ and $\mathrm{H} 2$ in core SU90-09. For example, present-day $\delta^{13} \mathrm{C}$ and $\delta^{15} \mathrm{~N}$ averages of $-21.9 \pm 0.4$ and $7.6 \pm 0.6 \%$ are observed in the Labrador Sea [Muzuka and Hillaire-Marcel, 1999]. SOM from deep basins of the Bering Sea yields $\delta^{13} \mathrm{C}$ and $\delta^{15} \mathrm{~N}$ of -20.5 to $-22.5 \%$ and $5.5-7.5 \%$, respectively, for the past 40,000 years B.P. [Nakatsuka et al., 1995]. These isotopic values are much closer to those obtained for ambient sediments $\left(\delta^{13} \mathrm{C}=-23.5 \pm\right.$ $0.7 \%$ and $\delta^{15} \mathrm{~N}=4.7 \pm 0.9 \%$ ) than for SOM deposited during $\mathrm{H} 1$ and H2. An alternative interpretation would be that SOM isotopic composition records an enhanced detrital supply of lithic and/or soil organic matter derived from continental sources of high-latitude regions. Such terrigenous supply may be estimated from studies of glacial sediments from the western Labrador, characterized by minimal isotopic values: $\delta^{13} \mathrm{C} \approx$ $27 \%$ and $\delta^{15} \mathrm{~N} \approx 2 \%$ [Muzuka, 1995]. In a more general way, soil and aquatic sources of organic matter located in cold areas should release material derived from " $\mathrm{C}_{3}$ plant" isotopic signatures [Farquhar et al., 1989]. Glacial erosion of "geological" sources can also provide detrital organic matter with comparable $\delta^{13} \mathrm{C}$ values, organic matter being represented by various continental and marine remains (i.e., CambrianJurassic records $-31 \%<\delta^{13} \mathrm{C}<-26 \%$, [Haynes et al., 1999]). Most of the available $\delta^{15} \mathrm{~N}$ data for arctic and subarctic vegetations point to low values $\left(-7.7 \%<\delta^{15} \mathrm{~N}<0.9 \%\right.$, [Schulze et al., 1994]), which even after various enrichment processes related to soil formation, are consistent with the ones observed for $\mathrm{H} 1$ and $\mathrm{H} 2$. Other tracers also point to terrigenous sources. Previous analysis from the twin core SU90-08 revealed the presence of this detrital and continental n-alkane components in HLs [Villanueva et al., 1998]. Some IRD intervals are characterized by a high content of coal [Heinrich et al., 1989]. Finally, optical examination of the organic matter reveals a large amount of continent-derived material, including abundant airborne material, such as spores, pollens, and cellulose-rich debris (E. Vergès, personal communication, 2000). Such an airborne particule enhancement is consistent with the simultaneous increase of dust observed during the Heinrich events in the Greenland ice cores [Mayewski et al., 1994] as already reported [Grousset et $a l ., 2000]$. Therefore, considering the important contribution of continental organic matter transported by ice rafting in the IRD belt, the isotopic composition of SOM should not be systematically considered as reflecting a marine signature (Huon et al., submitted manuscript, 2001), but, rather, reflecting a change in the source of SOM.

Using diatom proxies, Sancetta [1992] proposed that in the glacial Northern Pacific and Atlantic Oceans the presence of icebergs supported high production, owing to physical or biochemical mechanisms. This process should be considerably enhanced during HLs. It has not been possible, however, to observe such enhancements during HLs as diatoms totally disappear during these events in core SU90-09 (X. Pichon, personnal communication, 2000). This process can be adressed by looking at the $\delta^{15} \mathrm{~N}$ relative increases observed during $\mathrm{H}$ l and H2. A possible interpretation could be that increasing $\delta^{15} \mathrm{~N}$ values are related to more efficient surface water nutrient use [e.g., François et al., 1997]. Surface and bottom water exchanges could then temporarily occur between the discharge maximaobserved during $\mathrm{H} 1$ and $\mathrm{H} 2$. However, this question cannot be solely answered on the basis of stable isotope data as no clear relationship could be drawn between $\delta^{13} \mathrm{C}$ and $\delta^{15} \mathrm{~N}$ values or between $\delta^{15} \mathrm{~N}$ and paleosalinity estimates recorded by foraminifer $\delta^{18} \mathrm{O}$.

\section{Conclusions}

Zooming in on Heinrich layers (HLs) in a high-resolution mode (every $5 \mathrm{~mm}$ ) permits the extraction of a level of variability that has been poorly appreciated until now. Some conclusions can be drawn from this survey.

$\mathrm{H} 1$ and $\mathrm{H} 2$ are characterized by a three-step internal structure: during the first step, ice-rafted detritus (IRD) derived from the European ice sheets (Iceland, Fennoscandia, and British Isles) are released into the northern North Atlantic Ocean, displaying a so-called "precursor event" typified by volcanic grains and lasting $1-2$ centuries. A second step, which may occur 1.0-1.5 kyr after the beginning of the precursor event, is represented by a major input of Laurentidederived IRD, dominated by crust-derived particles, typified by a high abundance of quartz. Finally, during a last step, detrital carbonate from the remote Hudson and Baffin Bays are accumulated.

During a Heinrich event, IRD deposition is not a continuous process but reflects a time-transgressive, multisourced release of icebergs, inducing an intermittent sedimentation. These pulses occur on a centennial timescale $(\approx 2-5$ centuries) and could be due to a step-by-step collapse of the Laurentide ice sheet or to latitudinal oscillations of the trans-Atlantic IRD belt. Similar short centennial-scale pulses are observed along the European margin as well [Knutz et al., 2001].

The isotopic signature of fine-grained sedimentary organic matter included in $\mathrm{H} 1$ and $\mathrm{H} 2$ reveals a dominant continental 
origin with low values decreasing to -27.9 and $0.3 \%$ for $\delta^{13} \mathrm{C}$ and $\delta^{15} \mathrm{~N}$, respectively. These values are sharply contrasting with those of ambient sediments $\left(\delta^{13} \mathrm{C}=-23.5 \pm 0.7 \% 0\right.$ and $\delta^{15} \mathrm{~N}=4.7 \pm 0.9 \%$ ), mainly reflecting the glacial oceanic contribution.

In terms of HL origin, although the Laurentide surge is the major, dominant process characterizing a Heinrich event, the starting point of the entire sequence is a destabilization of the Icelandic and European ice sheets.

Acknowledgements. Most of the cores studied here were collected by IFREMER research vessels. IMAGES cores were recovered by the N/V Marion-Dufresne (French Polar Institute). We gratefully acknowledge J. Andrews, G. Auffret,
D. Boust, P. Knutz, and P. Martinez for their collegiality in sharing samples with us. P. Pédemay, G. Lavaux, B. Le Coat, J. Tessier, B. Hermann, and M. Roy-Barman provided invaluable technical assistance. Catherine Kissel kindly provided the high-resolution magnetic susceptibility record. We thank J. Andrews, L. Labeyrie, and F. Eynaud for comments and discussions. We thank P.E. Biscaye, M. Maslin, P.C. Knutz, and one anonymous reviewer for friendly and helpful improvements on the manuscript. AMS ${ }^{14} \mathrm{C}$ ages were measured by Beta Analytic Inc. Financial contributions from the European Community programme ENV4-CT97-0643 and the Centre National de la Recherche Scientifique programmes VARIENTE and ECLIPSE are acknowledged. Thomas Richter was supported through a postdoctoral fellowship by the Deutsche Forschungsgemeinschaft (grant Ri 963/1-1) at DGOBordeaux. This is UMR 5805 EPOC contribution 1385.

\section{References}

Alley, R.B., Icing the North Atlantic, Nature, $392,337-338,1998$.

Alley, R.B., and D.R. MacAyeal, Ice-rafted debris associated with binge/purge oscillations of the Laurentide Ice Sheet, Paleoceanography, 9, 503-511, 1994.

Andrews, J. T., Abrupt changes (Heinrich events) in late Quatemary North Atlantic marine environments: A history and review of data and concepts, J. Quat. Sct., 13, 3-16, 1998

Andrews J. T., and K. Tedesco, Detrital carbonate-rich sediments, northwestern Labrador Sea: Implications for ice-sheet dynamics and iceberg rafting (Heinrich) events in the North Atlantic, Geology, 20 1087-1090, 1992.

Auffret, G., A. Boelaert, C VergnaudGrazzini, C. Muller, and R. Kerbrat, Identification of Heinrich layers in core KS0 I North Eastern Atlantic $\left(46^{\circ} \mathrm{N}, 17^{\circ} \mathrm{W}\right)$, implications for their origin, Mar. Geol., 131, 5-20, 1996.

Bard, E., Correction of accelerator mass spectrometry ${ }^{14} \mathrm{C}$ ages measured in planktonic foraminifera: Paleoceanographic implications, Paleoceanography, 3, 635-645, 1988.

Bard, E., Geochemical and geophysical implications of the radiocarbon calibration, Geochim. Cosmo. Acta., 62, 2025-2038, 1998.

Bard, E, M. Amold, B. Hamelin, N. TisneratLaborde, and G. Cabioch, Radiocarbon calibration by means of mass spectrometric ${ }^{230} \mathrm{Th} /{ }^{234} \mathrm{U}$ and ${ }^{14} \mathrm{C}$ ages of corals: An updated database including samples from Barbados, Muruora and Tahiti, Radiocarbon, 40, 1085-1092, 1998.

Bischof, J.F., and D.A. Darby, Mid- to Late Pleistocene ice drift in the westem Arctic Ocean: Evidence for a different circulation in the past, Science, 277, 74-78, 1997.

Bischof, J.F., and D.A. Darby, Quaternary ice transport in the Canadian Arctic and extent of Late Wisconsinan Glaciation in the Queen Elizabeth Islands, Can. J. Earth ScI. 36, 2007-2022, 1999.

Bond, G. C., and R. Lotti, Iceberg discharges into the North Atlantic on millennial time scales during the last glaciation, Science, 267, 1005-1010, 1995

Bond, G., et al., Correlations between climate records from North Atlantic sediments and Greenland ice, Nature, 365, 143-147, 1992.

Bond, G.C., W. Showers, M. Elliot, M. Evans, R. Lotti, I. Hadjas, G. Bonani, and S Johnson, The North Atlantic's 1-2 kyr climate rythm: Relation to Heinrich events,
Dansgaard/Oeschger and the Little Ice Age in Mechanisms of Global Climate Changes at Millenial Timescales, Geophys Monogr. Ser., vol. 112, edited by P.U. Clark et al., pp. 35-58, AGU, Washington, D.C., 1999.

Broecker, W. S., Massive iceberg discharges as triggers for global climate change, Nature, 372, 421-424, 1994

Broecker, W. S., Themohaline circulation, the Achilles heel of our climate system: Will man-made $\mathrm{CO}_{2}$ upset the current balance? Science, 278, 1582-1588, 1997.

Chapman, M.R., and M.A. Maslin, Low-latitude forcing of meridional temperature and salinity gradients in the subpolar North Atlantic and the growth of glacial ice sheets, Geology, 27, 875-878, 1999.

Coplen, T.B., C. Kendall, and J. Hopple Comparison of stable isotope reference samples, Nature, 302, 236-238, 1983.

Cortijo, E., L. Labeyrie, L. Vidal, M Vautravers, M. Chapman, J.C. Duplessy, M Elliot, M. Amold, J.L. Turon, and G Auffret, Changes in sea-surface hydrology associated with Heinrich event 4 in the North Atlantic Ocean between $40^{\circ}$ and $60^{\circ} \mathrm{N}$, Earth Planet. ScI. Lett., 146, 29-47, 1997.

Dowdeswell, J.A., M.A. Maslin, J.T. Andrews, and I.N. McCave, lceberg production, debris rafting and the extent and thickness of "Heinrich layers" in North Atlantic sediments, Geology, 23, 301-304, 1995.

Dowdeswell, J.A., A. Elverøi, J.T. Andrews, and Hebbeln D., Asynchronous deposition of ice-rafted layers in the Nordic seas and North Atlantic Ocean, Nafure, 400, 348-351, 1999.

Elderfield, H., Strontium isotope stratıgraphy, Palaeogeogr. Palaeoclimatol. Paloeoecol., 57, 71-90, 1986

Elliot, M., L. Labeyrie, G. Bond, E. Cortijo, J.L. Turon, N. Tisnerat, and J.C. Duplessy, Millenial-scale iceberg discharges in the Iminger Basin during the last glacial period. Relationship with the Heinrich events and environmental settings, Paleoceanography, 13, 433-446, 1998

Farquhar, G.D., J.R. Ehleringer, and K.T Hubick, Carbon isotope discrimination and photosynthesis, Ann. Rev. Plant Phys. Plant Mol. Biol. 40, 503-537, 1989.

François, R., and M.P. Bacon, Heinrich events in the North Atlantic: Radiochemisa evidence, Deep Sea Res., Part I, 4I, 315334, 1994.

Francois, R., M.A. Altabet, E.F. Yu, D.M Sigman, M.P. Bacon, M. Franck, G. Bohmann, G. Bareille, and L.D. Labeyrie, Contribution of Southem Ocean surface- water stratification to low atmospheric $\mathrm{CO}_{2}$ concentrations during the last glacial period, Nature, 389, 929-935, 1997.

Goldstein, S.J., and S.B. Jacobsen, Nd and St isotopic systematics of river water suspended material: Implications for crustal evolution, Earth Planet. Sci. Lett., 87, 249265, 1988

Grousset, F.E., L. Labeyrie, J.A. Sinko, M Cremer, G. Bond, J. Duprat, E. Cortijo, and $S$. Huon, Patterns of ice-rafted detritus in the glacial north Atlantic $\left(40^{\circ}-55^{\circ} \mathrm{N}\right)$ Paleoceanography, 8, 175-192, 1993.

Grousset, F.E., M. Parra, A. Bory, P. Martinez, P. Bertrand, G. Shimmield, and R. Ellam Saharan wind regimes traced by the Sr-Nd isotopic composition of the tropical Atlantic sediments: Last Glacial Maximum vs. today, Quat. Science Rev., 17, 395-409, 1998.

Grousset, F.E., C. Pujol, L. Labeyrie, G Auffret, and A. Boelaert, Were the North Atlantic Heinrich Events triggered by the behavior of the European ice sheets? Geology, 28, 123-126, 2000.

Gwiazda, R.H, S.R. Hemming, and W.S Broecker, Tracking the sources of icebergs with lead isotopes: The provenance of icerafted debris in Heinrich layer 2 Paleoceanography, $11,77-93,1996 \mathrm{a}$.

Gwiazda, R.H, S.R. Hemming, and W.S Broecker, Provenance of icebergs during Heinrich event 3 and their contrast to their sources during other Heinrich episodes, Paleoceanography, II, 371-378, 1996b.

Heinrich, H., Origin and consequences of cyclic ice rafting in the northeast Atlantic Ocean during the past 130,000 years, Quat. Res., 29, 142-152, 1988.

Hemming, S.R., W.S. Broecker, W.D. Sharp, G.C. Bond, R.H. Gwiazda, J.F. McManus, M. Klas, and I. Hajdas, Provenance of Heinrich layers in core V28-82 northeastern Atlantic: $40 \mathrm{Ar} / 39 \mathrm{Ar}$ ages of ice-rafted hornblende, $\mathrm{Pb}$ isotopes in feldspar grains, and $\mathrm{Nd}-\mathrm{Sr}-\mathrm{Pb}$ isotopes in the fine sediment fraction, Earth Planet. Sci. Lett. . 164, 317-333, 1998.

Henrich, R., H. Kassens, E. Vogelsang, and J. Thiede, Sedimentary facies of glacialinterglacial cycles in the Norwegian Sea during the last $350 \mathrm{ka}, \mathrm{Mar}$. Geol., 86, 283319. 1989.

Huon, S., and R Jantschik, Detrital silicates in Northeast Atlantic deep-sea sediments during the Late Quaternary, Major elements, REE, Rb-Sr isotopic data, Eclogae Geol. Helv., 86, 195-212, 1993.

Jacobsen, S.B., and G.J Wasserburg. Sm-Nd isotopic evolution of chondrites, Earth Planet. Sc.. Lett., 50, 139-155, 1980. 
Keffer, T., D.G. Martinson, and B.H. Corliss, The position of the Gulf Stream during the Quaternary glaciations, Science, 24I, 440442,1988 .

Knutz, P.C. W.E.N. Austin, and E.J W. Jones, Millenial-scale depositional cycles related to British ice sheet varıability and North Atlantic paleocirculation since $45 \mathrm{kyr}$ B.P., Barra Fan, UK margin, Paleoceanography, 16. 53-64, 2001.

MacAyeal, D. R, Binge/purge oscillations of the Laurentide ice sheet as a cause of the North Atlantic's Heinrich events, Paleoceanography, 8, 775-784, 1993

Mayewski, P.A, et al., Changes in atmospherıc circulation and ocean ice-cover over the north Atlantic during the last 41 kyr, Science, 263, 1747-1751, 1994.

McCabe, A M, and P.U. Clark, Ice-sheet variability around the North Atlantic ocean during the last deglaciation, Nature, 392 , 373-377, 1998

McCulloch, M.T., and G.J. Wasserburg, Sm$\mathrm{Nd}$ and $\mathrm{Rb}-\mathrm{Sr}$ chronology of continental crust formation, Sctence, 200, 1003-1011, 1978

McManus, J.F., R.F. Anderson, W S. Broecker, MQ. Fleisher, and S.M. Higgins, Radiometrically determined fluxes in the subpolar North-Atlantic during the pas 140,000 years, Earth Planet. ScI. Lett., 155 29-43, 1998.

Migeon, S, O. Weber, J.C. Faugères, and J. Saint-Paul, SCOPIX A new X-ray imaging system for core analysis, Geo Mar. Lett., 18 251-255, 1999.

Miller, R G., and R.K. O'Nions, The provenance and crustal residence ages of British sediments in relation to paleogeographic reconstructions, Earth Planet. Sci. Lett., 68, 459-470, 1984.

Miller, R.G., and R.K. O'Nions, Source of Precambrian chemical and clastic sediments, Nature, 314, 325-330, 1985.

Muzuka, A.N.N., Burial rate and diagenetic changes of nitrogen bearing organic matter in the subarctic northwest Atlantic, $P h D$ thesis, $262 \mathrm{pp}$., Univ. du Québec à Montréal Montréal, Canada, 1995.

Muzuka, A.N.N., and C. Hilaire-Marcel, Burial rates of organic matter along the eastern Canadian margin and stable isotope constraints on its origin and diagenetic evolution. Mar. Geol., I60, 251-270, 1999.

Nakatsuka, T., K. Watanabe, N. Handa, and E. Matsumoto, Glacial and interglacial surface nutrient variations of Bering deep basins recorded by $\delta^{13} \mathrm{C}$ and $\delta^{15} \mathrm{~N}$ of sedimentary organic malter, Paleoceanography, I0, 1047-1061, 1995

Paillard, D., L. Labeyrie and P. Yiou, Macintosch program performs time-series analysis, Eos Trans. $A G U, 77(39), 379$, 1996, (Available as http://www.agu org/eos_ elec/96097e.html)

Prell, W.L., The stability of low-latitude seasurface temperature: An evolution of the CLIMAP reconstruction with emphasis on the positive SST anomalies, U.S. Dep. Energy, Tech. Rep., 25, 60 pp., 1985.

Rahman, A., Reworked nannofossils in the North Allantic Ocean and subpolar basins. Implications for Heinrich events and ocean circulation, Geology, 23, 487-490, 1995.

Revel, M., J.A. Sinko, F.E. Grousset, and P.E. Biscaye, Sr and Nd isotopes as tracers of North Atlantic lithic particles: Paleoclimatic implications, Paleoceanography, $11,95-113$, 1996.

Ruddiman, W F., Late Quaternary deposition of ice-rafted sand in the sub-polar North Atlantic (lat. $40^{\circ}$ to $65^{\circ}$ ), Geol. Soc. Am. Bull., 88, 1813-1821, 1977 .

Sancetta, C. Primary production in the glacial North Atlantic and North Pacific oceans, Nature, 360, 249-251, 1992.

Schafer-Neth, C., and K. Statteger, Meltwater pulses in the northern North Atlantic: Retrodiction and forecast by numerical modelling, Geol. Rundsch., 86, 492-498, 1997.

Schultze, E.D., F.S.I. Chapin, and G. Gebauer, Nitrogen nutrition differences among life forms at the northern treeline of Alaska, Oecologia, 100, 536-542, 1994.

Scourse, J.D., I.R. Hall, I.N. McCave, J.R. Young, and $C$. Sugdon, The origin of Heinrich layers: Evidence from H2 for European precursor events, Earth Planet. Sci Lett., I82, 187-195, 2000.

Snoeckx, H., F.E. Grousset, M. Revel, and A Boelaert, European contribution of icerafted sand to Heinrich layers $\mathrm{H3}$ and $\mathrm{H} 4$, Mar. Geol., 158, 197-208, 1999
Stordal, M.C., and G.J. Wasserburg, Nd isotopic study of Baffin Bay water: Sources of REE from very old terranes, Earth Planet. Scl. Lett., 77, 259-272, 1986.

Stuiver, M., P. Reımer, E. Bard, W. Beck, G S Burr, K A. Hughen, B. Kromer, G McCormac, J. Van der Plicht, and M Spurk, INTCAL-98 radiocarbon age calibration, 24,000-0 cal BP, Radiocarbon, 40, 10411083, 1998

Van Kreveld, S, M. Sarntheın, H. Erlenkeuser, P. Grootes, S. Jung, M.J Nadeau, U Pflauman, and A Voelker, Paleoceanography, 15, 425-442, 2000

Vidal, L., L. Labeyrie, E. Cortijo, M. Arnold, J.C. Duplessy, E. Michel, S. Becqué, and T.C.E. van Weering, Evidence for changes in the North Atlantic Deep water linked to meltwater surges during Heinrich events, Earth Planet. Sal Lett., 146, 13-27, 1997.

Villanueva, J., J.O. Grimalt, L.D. Labeyrie, E. Cortijo, L. Vidal, and J.L. Turon, Precessional forcing and productivity in the North Atlantic Ocean, Paleoceanography, 13, 101-117, 1998

Zahn, R., J. Schönfeld, H.R Kudrass, M.H. Park, H. Erlenkeuser, and P. Grootes, Thermohaline instability in the North Atlantic during meltwater events: Stable isotopes and ice-rafted detritus records from core SO75-26KL, Portuguese margin, Paleoceanography, 12, 696-710, 1997.

D Burdloff, J. Duprat, F.E. Grousset, L Hervé, $T$ Richter, ${ }^{1}$ and $O$. Weber, Département de Géologıe et Océanographe, UMR 5805 EPOC, Unıversité Bordeaux I, Avenue des Facultés, 33405 Talence cedex, France (j duprat 1 geocean u-bordeaux fr, grousset@geocean.u-bordeaux fr, weber@geocean ubordeaux.fr)

E Cortijo, Laboratoire des Sciences du Climat et de l'Environnement, CNRS-CEA, Avenue de la Terrasse, 91198 Gif sur Yvette cedex, France (Elsa cortijo@lsce cnrs-gif fr)

S. Huon, BioGéochimie Isotopıque, UMR 7618, Unıversité Parıs 6, Case 120, 4 Place Jussieu, 75252 Pans cedex 5, France (huon@ccr jussieu fr)

(Received June 30, 2000, revised January 10, 2001, accepted January 26, 2001 ) 